\title{
Responses of Moringa oleifera to alteration in soil properties induced by calcium nanoparticles (CaNPs) on mineral absorption, physiological indices and photosynthetic indicators
}

\author{
Luqmon Azeez $^{1 *}$ (D), Agbaje Lateef ${ }^{2}$ (D) , Rasheed O. Adetoro ${ }^{1}$ and Adebayo E. Adeleke ${ }^{3}$
}

\begin{abstract}
Background: The application of nanofertilisers in agriculture has been widely utilised due to their distinct characteristics and negative impacts of conventional chemical fertilisers. This study thus examined the influence of calcium nanoparticles (CaNPs) on soil composition vis-à-vis performance parameters in Moringa oleifera L exposed to water, $100 \mathrm{mg} \mathrm{Ca}\left(\mathrm{NO}_{3}\right)_{2} \mathrm{~kg}^{-1}$ soil and 100, 75 and $50 \mathrm{mg} \mathrm{CaNPs} \mathrm{kg}^{-1}$ soil. Soil morphology was determined with a scanning electron microscope coupled with energy dispersive x-ray (SEM-EDX) and elemental composition in both soils and $M$. oleifera roots determined with inductively coupled plasma-optical emission spectrometer (ICPOES).

Results: The CaNP-amended soils were more crystalline, more fertile and had reduced salinity. An increase in immobilisation percentage of heavy metals, improvement in physiological parameters (percentage germination, vigour indices, relative water contents, lengths of roots and shoots) and photosynthetic efficiency in M. oleifera were recorded.

Conclusion: This study has demonstrated that CaNPs could improve soil composition for better plant performance and can act as nanofertilisers mobilising essential nutrients.
\end{abstract}

Keywords: Nanoparticles, Mineral nutrients, Photosynthetic indicators, Soil fertility, Immobilisation

\section{Background}

Soil is a repository of nutrients as well as a sink for pollutants. Soil chemical properties are quality indicators to determine soil fertility, soil health and exchangeable cation abilities. Soil matrix is a central medium via which vegetables absorb macro- and micronutrients required for their growth [1-3]. The efficiency of vegetable production is directly associated with the potential contribution of soil nutrients. Inadequate soil fertility requires

\footnotetext{
* Correspondence: luqman.azeez@uniosun.edu.ng

${ }^{1}$ Department of Pure and Applied Chemistry, Osun State University, Osogbo, Nigeria

Full list of author information is available at the end of the article
}

the use of fertilisers. Ecological problems, the formation of organo-mineral precipitates and inefficient plant usage made necessary the search for alternatives to conventional agrochemicals [2, 4-9].

Applications of metal nanoparticles have remarkably improved agricultural practices as nanofertilisers to promote plant growth and enhance nutritional quality, as nanopesticides to protect against phytopathogens and as immobilising/adsorbing agents for soil pollutants $[8,10-14]$. Metal nanoparticles as soil conditioners and plant growth enhancers have been reported in some studies; some had stimulatory actions while some were phytotoxic. Studies on 
stimulatory actions of metal nanoparticles showed improved antioxidant activities, increased germination percentage and longer roots and shoots whereas their phytotoxicity manifested in increased malondialdehyde level and reduced antioxidant enzyme activities [1, 9, $15,16]$.

Metal nanoparticles can be used as nanofertilisers supplying essential minerals or be applied to improve the performance of conventional chemical fertilisers. They are more efficient in supplying nutrients and contribute lesser environmental pollution because of their controllable rates of release thereby reducing the risk of nutrient run-off into water [3, 5, 11-14, 17-21].

Nanoparticles in soil interact with plant roots and get translocated along with soil nutrients to other plant tissues. Their dispersal in soil facilitates the uptake of essential minerals and nutrients required for activation of enzymes such as $\mathrm{Se}$ and $\mathrm{Cu}$ for glutathione peroxidase, $\mathrm{Mg}$ and $\mathrm{Fe}$ superoxide dismutase and $\mathrm{Fe}$ and ascorbate $[22,23]$. Nanoparticles are known to immobilise heavy metals and serve as adsorbents for pollutants $[8,12,15]$. They boost the synthesis of phytochemicals which defend plants against environmental stress and infections of pathogenic organisms. They improve chlorophyll contents, carotenoids and antioxidant activities to enrich nutritional components of vegetables [24-26].

Moreover, nanopesticidal properties of nanoparticles involve specificity towards targeted pests with little or no harmful effects on non-target or beneficial microbes, permeability to ensure availability when needed, stability to aggregation and conditional controllable release to maximise efficiency over a long period to prevent environmental pollution. These make them crop-friendly as crops would not contend with a high dose of pesticides unlike conventional pesticides $[1,8,13,14,17,19,27-36]$.

Many studies have reported the effectiveness of metal and non-metal nanoparticles as nanopesticides and nanofertilisers. Nanoparticles containing $\mathrm{Ag}, \mathrm{Cu}$, $\mathrm{Au}, \mathrm{Mn}, \mathrm{Fe}, \mathrm{Ti}, \mathrm{Zn}$, fullerene (C60), Mg, hydroxyapatite, Mo stimulated growth, increased biomass, elongated root and shoot length, improved vigour indices, promoted germination, reduced oxidative stress biomarkers and immobilised heavy metals in Moringa oleifera, Corchorus olitorus, Amaranthus caudatus, Spinacia oleracea, Momordica charantia Populus deltoids, Solanum lycopersicum, Zea mays, Brassica juncea, Citrullus lanatus, Cucurbita pepo, Oryza sativa, Raphanus sativum, Arabidopsis thaliana, Gloriosa superba and Hordeum vulgare [1, 4, 8-15, 18]. Nanoparticles containing $\mathrm{Cu}, \mathrm{Ag}, \mathrm{Au}, \mathrm{Zn}$, $\mathrm{Zn} / \mathrm{Mg}, \mathrm{Ag} / \mathrm{Si}$ and $\mathrm{Ti}$ have also been reported to modify microbial activities in soil, suppress the population of Aspergillus terreus, A. niger, Fusarium spp., Bipolaris sorokiniana, Phytophthora parasitica, Artemisia absinthium, Sclerotium cepivorum, Colletotrichum gloeosporioides, Bacillus subtilis, Pseudomonas fluorescens, and Trichoderma Viride, Alternaria alternata, Cladosporium spp and exterminate Meloidogyne spp [21, 33, 36-40].

Moringa oleifera Linn is a source of minerals, protein, vitamins, polyphenols, fibre and carotenoids [41-45]. The presence of soil pollutants can hinder bioavailability of essential nutrients needed by M. oleifera for growth.

Calcium nanoparticles (CaNPs) can assist in improving soil fertility, assist in the mobility of some trace mineral elements and assist in the probable immobility of heavy metals which are of no biological interest [36, 37, 46]. $\mathrm{Ca}_{3}\left(\mathrm{PO}_{4}\right)_{2}$ nanoparticles have been reported to enhance root and shoot elongations, improve antioxidant enzyme activities and reduce lipid peroxidation levels in rice [40].

Evidence on functions of zero-charged calcium nanoparticles (CaNPs) mediated with $\mathrm{Ca}\left(\mathrm{NO}_{3}\right)_{2}$ and pod extract of Kola (Cola nitida S) on soil composition, heavy metal remediation, mobilisation of essential minerals, improvement of plant physiology and as photosynthetic indicators has yet to be reported since nanoparticles undergo different transformations in soil. The study was undertaken to determine the influence of CaNPs on soil properties, nutrient/fertility status and stimulatory/phytotoxicity potentials on M. oleifera planted on amended soils with CaNPs as an alternative to conventional fertilisers.

\section{Methods}

\subsection{Green synthesis of CaNPs and determination of its point of zero charge}

CaNPs were synthesised using the pod extract of Cola nitida, which was obtained by extracting $1.0 \mathrm{~g}$ of dried pod in $100 \mathrm{ml}$ of water at $60{ }^{\circ} \mathrm{C}$ for $1 \mathrm{~h}$. Thereafter, $15 \mathrm{ml}$ of the extract was reacted with $150 \mathrm{ml}$ of $1 \mathrm{mM} \mathrm{Ca}\left(\mathrm{NO}_{3}\right)_{2}$ at $60{ }^{\circ} \mathrm{C}$ for $1 \mathrm{~h}$, leading to the formation of a deep golden brown colloidal solution, which absorbed maximally at $215 \mathrm{~nm}$. Synthesised CaNPs were characterised using transmission electron microscopy, Fourier Infra-red spectroscopy and UVVisible spectroscopy.

The $\mathrm{pH}$ point of zero charge (pHpzc) of 100, 75 and $50 \mathrm{mgL}^{-1} \mathrm{CaNPs}$ and $100 \mathrm{mgL}^{-1} \mathrm{Ca}\left(\mathrm{NO}_{3}\right)_{2}$ was determined by adding $10 \mathrm{ml}$ of each concentration separately to $200 \mathrm{ml} 0.1 \mathrm{M} \mathrm{NaCl}$ with known $\mathrm{pH}$. The $\mathrm{pH}$ was adjusted between 1 and 10 with $0.1 \mathrm{M} \mathrm{NaOH}$ or $0.1 \mathrm{M}$ $\mathrm{HCl}$. Final $\mathrm{pH}$ values were taken after $24 \mathrm{~h}$ with Jenway $6405 \mathrm{pH}$ meter (Germany). A plot of the difference in $\mathrm{pH}$ (final - initial) against initial $\mathrm{pH}$ was made and the point of intersection on the horizontal axis is the pHpzc. 


\subsection{Soil and plant collection, analysis and morphological} characteristics

Soil samples were collected from a farm located on latitude $7^{\circ} 759502^{\prime} \mathrm{N}$ and longitude $4^{\circ} 599194^{\prime} \mathrm{E}$ at a depth between 0 and $25 \mathrm{~cm}$, air dried, pulverised and sieved with a $600-\mu \mathrm{m}$ wire mesh.

Methods described by $[47,48]$ were used for the analysis of soil $\mathrm{pH}$, organic carbon, phosphorus, nitrogen, soil texture and composition and cation exchange capacity. Exchangeable sodium percentage (ESP) was calculated with Eq. 1. ESP is a useful measure of $\mathrm{Na}$ on soil properties.

$$
E S P=N a /[K+C a+M g+N a]
$$

Mineral and heavy metal analysis was done by digesting $1 \mathrm{~g}$ of air-dried pre-planting, post-harvesting soil and $M$. oleifera root separately with a mixture of concentrated $\mathrm{HNO}_{3}$ and $\mathrm{HCl}$ (7:3). The solution was boiled at $100{ }^{\circ} \mathrm{C}$, allowed to cool, filtered and made up to $20 \mathrm{ml}$ with deionised distilled water. The soil sample was analysed in triplicate.

An inductively coupled plasma with optical emission spectrometer (ICP-OES, Agilent 720-ES, USA) was employed for the analysis of $\mathrm{Na}, \mathrm{K}, \mathrm{Ca}, \mathrm{Mg}, \mathrm{Zn}, \mathrm{Cu}, \mathrm{Fe}$, $\mathrm{Ni}, \mathrm{Mn}, \mathrm{Pb}, \mathrm{Cd}, \mathrm{Cr}$ and $\mathrm{As}$ in soil. The instrument was rinsed with $5 \% \mathrm{HNO}_{3}$ after which blank was run and then targeted metals without interference at emission lines $\mathrm{Zn} \mathrm{(213.857),} \mathrm{Cu} \mathrm{(327.395),} \mathrm{Pb} \mathrm{(220.353),} \mathrm{Ni}$ (231.604), Fe (238.204), Cd (214.439), Mn (217.610), Cr (267.716), Mg (279.553), Ca (396.847), Na (589.592), K (766.491) and As (188.980) were analysed. Reproducibility of the instrument was ensured by plotting calibration curves of metal standards with regression equation $\mathrm{R}^{2}=$ 0.995 .

Morphological characteristics and elemental composition of both pre-planting and post-harvesting soil were determined using scanning electron microscopy and energy dispersive x-ray (SEM-EDX, JEOL JSM-7600F).

Adsorption (immobilisation) capacity of amended soils for heavy metal was calculated with Eq. 2.

Heavy metal adsorption $=\frac{\text { Concentration in pre-planting soil-concentration in post-harvest soil }}{\text { Concentration in pre-planting soil }} \times 100$

\subsection{CaNPs amendment of soil and planting of M. oleifera seeds}

Twenty-five ( 5 for each group) non-perforated buckets (75 mL) were filled each with $250 \mathrm{~g}$ of air-dried, pulverised and filtered soil. Moringa oleifera seeds were exposed to water, $100 \mathrm{mg} \mathrm{Ca}\left(\mathrm{NO}_{3}\right)_{2} \mathrm{~kg}^{-1}$ soil, $100 \mathrm{mg}$ CaNPs $\mathrm{kg}^{-1}$ soil, $75 \mathrm{mg}$ CaNPs $\mathrm{kg}^{-1}$ soil and $50 \mathrm{mg}$ CaNPs $\mathrm{kg}^{-1}$ soil as groups A, B, C, D and E respectively for 3 weeks. Groups A and B served as positive and negative controls respectively. $M$. oleifera plants were maintained under day and night cycles of $12 \mathrm{~h}$ for 3 weeks at a UV index $(5.11 \pm 1.15)$, temperature $(29.14 \pm$ $\left.0.06{ }^{\circ} \mathrm{C}\right)$, relative humidity $(35.87 \pm 2.14 \%)$ and light intensity (13255 \pm 40.92 illuminance).

\subsection{Determination of germination indices in $M$. oleifera}

$M$. oleifera were planted to maturity and harvested after 3 weeks. Percentage germination, root and shoot lengths, vigour index and relative water contents were determined in $M$. oleifera as previously reported by $[8,12]$.

\subsection{Mineral nutrients in roots and absorption percentage in $M$. oleifera plant}

Di-acid digestion using $\mathrm{HNO}_{3}: \mathrm{HClO}_{4}$ (9:4) was used for digesting $0.5 \mathrm{~g}$ each of dried $\left(70{ }^{\circ} \mathrm{C}\right.$ for $\left.2 \mathrm{~h}\right) \mathrm{M}$. oleifera root in $10 \mathrm{ml} \mathrm{di-acid.} \mathrm{The} \mathrm{solution} \mathrm{was} \mathrm{placed} \mathrm{on} \mathrm{a} \mathrm{heat-}$ ing mantle programmed at $85{ }^{\circ} \mathrm{C}$, increased to $120{ }^{\circ} \mathrm{C}$ and heated continuously until the fumes ceased. It was made up to $20 \mathrm{ml}$ with deionised-distilled water. Mineral and heavy metal contents were determined using ICPOES as described in Section 2.2.

Metal absorption from the soil by root was calculated using Eq. 3 [8].

$$
\begin{aligned}
& \text { Percentage metal absorption } \\
& \quad=\frac{\text { metal content in root }}{\text { metal content in soil }} \times 100
\end{aligned}
$$

\subsection{Photosynthetic pigment contents in M. oleifera}

Chlorophyll a, b and carotenoid contents were measured in $M$. oleifera as described by [49]. $0.1 \mathrm{~g}$ of the fresh leaves was homogenised in $5 \mathrm{ml}$ ice-cold $80 \%$ acetone, centrifuged at $5000 \mathrm{rpm}$ for $5 \mathrm{~min}$ and then reextracted with $2.5 \mathrm{ml}$ of ice-cold $80 \%$ acetone twice. The absorbance of the combined extract was measured at 470, 663, $645 \mathrm{~nm}$ and their quantities expressed as $\mathrm{mg} / \mathrm{g}$ FW calculated using Eqs. 4-6.

$$
\begin{aligned}
& \text { Chlorophyll } a=12.25 \times A_{663}-2.79 \times A_{645} \\
& \text { Chlorophyll } b=21.50 \times A_{645}-5.10 \times A_{663}
\end{aligned}
$$

(Total chlorophyll $=$ Chlorophyll $\mathrm{a}+$ chlorophyll b)

$$
\text { Carotenoid }=\frac{\left(1000 \times A_{470}-1.82 \times C h l a-85.02 \times C h l b\right)}{198}
$$

\subsection{Statistical analysis}

Results of mineral contents, photosynthetic pigments and relative water contents are expressed as mean \pm standard deviation of three replicates. Results of root length, shoot length, vigour index, number of leaves and percentage germination are expressed as mean \pm 
standard deviation of fourteen replicates. These results were subjected to one-way ANOVA. Duncan's multiple range test was used for the comparison of means. The level of significance was performed at $\mathrm{p}<0.05$ using IBM SPSS 20 version.

\section{Results}

\subsection{Biosynthesis of CaNPs}

Calcium nanoparticles (CaNPs) mediated using the pod extract of $C$. nitida are a deep golden brown colloidal solution which absorbed maximally at $215 \mathrm{~nm}$. It is made up of a meshwork of particles of about $80 \mathrm{~nm}$ in size (Fig. 1a). FTIR spectrum of CaNPs showed peaks at $3424 \mathrm{~cm}^{-1}$ indicating $\mathrm{N}-\mathrm{H}$ vibrations and at $1711 \mathrm{~cm}^{-1}$ suggesting $\mathrm{C}=\mathrm{O}$ of ketone (Fig. 1b). This implies the presence of biomolecules needed for capping and stabilising nanoparticles in the extract of $C$. nitida. The colloidal CaNPs were used as obtained from the Laboratory of Industrial Microbiology and Nanobiotechnology, LAUTECH, Ogbomoso, Nigeria, except for dilution to obtain necessary concentrations for the study.

$\mathrm{pH}$ point of zero charge $\left(\mathrm{pH}_{\mathrm{pzc}}\right)$ of $\mathrm{Ca}\left(\mathrm{NO}_{3}\right)_{2}, 100,75$ and $50 \mathrm{mgL}^{-1} \mathrm{CaNPs}$ are 6.58, 6.51, 6.51 and 6.50 respectively. At $\mathrm{pH}<\mathrm{pH}_{\mathrm{pzc}}$, the surfaces of these solutions will be cationic and at $\mathrm{pH}>\mathrm{pH}_{\mathrm{pzc}}$, their surfaces will be anionic.

\subsection{Soil quality indicators, elemental composition, morphology and adsorption}

Soil quality indicators are essential parameters to measure fertility and their consequences on plant growth in addition to contributions to other activities involved in plant germinations and sustenance. Pre-planting (raw) soil in this study (Table 1) was inherently dark, sandy loam, slightly silty, slightly acidic with a sufficiently good percentage of organic carbon and organic matter soil texture. CaNPs beneficially enhanced nitrogen contents by $6.73,5.18$ and $2.28 \%$ in $\mathrm{C}, \mathrm{D}$ and $\mathrm{E}$ respectively (Table 1). Nitrogen contents were significantly higher in soils amended with $\mathrm{Ca}\left(\mathrm{NO}_{3}\right)_{2}$ and all concentrations of CaNPs while A (water) had comparable $\mathrm{N}$ contents with F (pre-amended) (Table 1). Phosphorus contents in all soils were comparable with soil $\mathrm{C}$ amended with CaNPs having a slightly higher content $(1.9 \%)$ than $\mathrm{F}$ while others had minimally reduced contents. Statistically significant $(p<0.05)$ decrease in organic matter and percentage organic carbon in groups $\mathrm{A}, \mathrm{B}, \mathrm{D}$ and $\mathrm{E}$ were obtained compared to $\mathrm{F}$ although $\mathrm{C}$ had a comparable organic matter and percentage organic carbon contents to pre-amended (F) but with a slight decrease (Table 1). An insignificant $(\mathrm{p}>0.05)$ increase in $\mathrm{pH}$ was obtained for soil amended with $100 \mathrm{mg} \mathrm{Ca}\left(\mathrm{NO}_{3}\right)_{2}, 100$ (group C), 75 (group D) and $50 \mathrm{mgL}^{-1}$ CaNPs (group E) whereas a slight decrease was recorded for soil watered with water compared to pre-amended soil (F). Increase in soil $\mathrm{pH}$ was not concentration-dependent. The $\mathrm{pH}$ values of respective soils amended with these solutions are higher than respective $\mathrm{pH}_{\mathrm{pzc}}$ of CaNPs and $\mathrm{Ca}\left(\mathrm{NO}_{3}\right)_{2}$ indicating their surface charges in the soil possibly as anionic. Percentage of clay, silt and sand in amended soil remained largely similar to pre-amended soil.

Raw soil had reasonably moderate available $\mathrm{N}, \mathrm{P}, \mathrm{Cu}$, $\mathrm{Mn}, \mathrm{Zn}, \mathrm{Fe}, \mathrm{K}, \mathrm{Ca}, \mathrm{Mg}, \mathrm{Na}$ and $\mathrm{Be}$ as well as a poor source of $\mathrm{Cd}, \mathrm{Cr}, \mathrm{Pb}$ and As. Abundance of mineral elements in raw soil follows $\mathrm{K}>\mathrm{Fe}>\mathrm{Ca}>\mathrm{Mg}>\mathrm{Na}>\mathrm{Cu}$ $>\mathrm{Zn}>\mathrm{Mn}>\mathrm{Cd}>\mathrm{Pb}>\mathrm{Cr}>\mathrm{Be}>\mathrm{Cr}>$ As. Concentrations of $\mathrm{K}, \mathrm{Zn}, \mathrm{Na}, \mathrm{Cu}, \mathrm{As}, \mathrm{Pb}, \mathrm{Cd}, \mathrm{Cr}$ and $\mathrm{Ni}$ (Table 1) were significantly $(\mathrm{p}<0.05)$ reduced in amended soils in comparison with $\mathrm{F}$ (raw). Concentrations of $\mathrm{Ca}$ were significantly $(\mathrm{p}<0.05)$ higher in soils $\mathrm{B}, \mathrm{C}, \mathrm{D}$ and $\mathrm{E}$ than in $\mathrm{F}$ while A had comparable concentration with F. Concentrations of $\mathrm{Fe}, \mathrm{Mn}$ and $\mathrm{Mg}$ were statistically insignificantly ( $p>0.05$ ) altered in all soils except for $\mathrm{Mn}$ in soil $\mathrm{E}$ compared with $\mathrm{F}$ (Table 1). Availability of macro and micronutrients such as $\mathrm{Ca}, \mathrm{N}$ and $\mathrm{Fe}$ in amended soil were higher than in pre-amended whereas the presence of toxic heavy metals was consequently immobilised.

Raw soil cation exchange capacity (CEC) was determined as $8.06 \pm 0.66 \mathrm{cmol}_{\mathrm{C}} \mathrm{Kg}^{-1}$ with a calculated exchangeable sodium percentage (ESP) of $0.11 \mathrm{cmol}_{\mathrm{c}} \mathrm{Kg}^{-1}$. Soils in B, D and E had a comparable proportion of CEC as F. Group $C$ had significantly $(\mathrm{p}<0.05)$ greater CEC than $\mathrm{F}$ while $\mathrm{A}$ had significantly lower CEC than $\mathrm{F}$. CaNPs beneficially improved CEC by $2.81 \%$ and 11.27 $\%$ over $\mathrm{F}$ and $\mathrm{A}$ respectively. Higher $\mathrm{CEC}$ in soil amended with $100 \mathrm{mgL}^{-1}$ CaNPs is an indication of a highly reactive and more negatively charged the soil.

Raw soil had a semi-porous nearly closely packed oval morphological structure (Fig. 2) with presence of $\mathrm{O}$ (29.45\%), Si (34.80\%), Ca (5.21\%), Na (7.90\%), Mg (2.40\%), N (3.66 \%), C (9.84\%) and $\mathrm{Al}(0.84 \%)$ as obtained in EDX (Table 2). Conspicuous alterations in morphological characteristics (Fig. 2) were recorded in SEM images of amended soils. A more crystalline soil with hollows was recorded for A and D even though, A had more pores than D which appeared more fused. A sheet-like with well carved-out cavities was obtained for $B$; a sponge tissue-like soil structure with mostdeveloped pores for $\mathrm{C}$ and a rod-like organised structure was recorded for E. Energy dispersive X-ray analysis (Fig. 2, Table 2) revealed an improved percentage $\mathrm{O}$ in $\mathrm{A}, \mathrm{B}, \mathrm{D}$ and $\mathrm{E}$ with a slight reduction in $\mathrm{C}$ compared with raw. All groups had decreased $\mathrm{Si}$ with $\mathrm{C}$ having comparable content with respect to $\mathrm{F}$. Soil $\mathrm{C}$ had higher $\mathrm{Ca}$, lower $\mathrm{Na}$ than other soils and more importantly the presence of Ag mobilised from the soil matrix. Results of elemental compositions (Table 2) determined with EDX show similarities with ICP-OES data. 


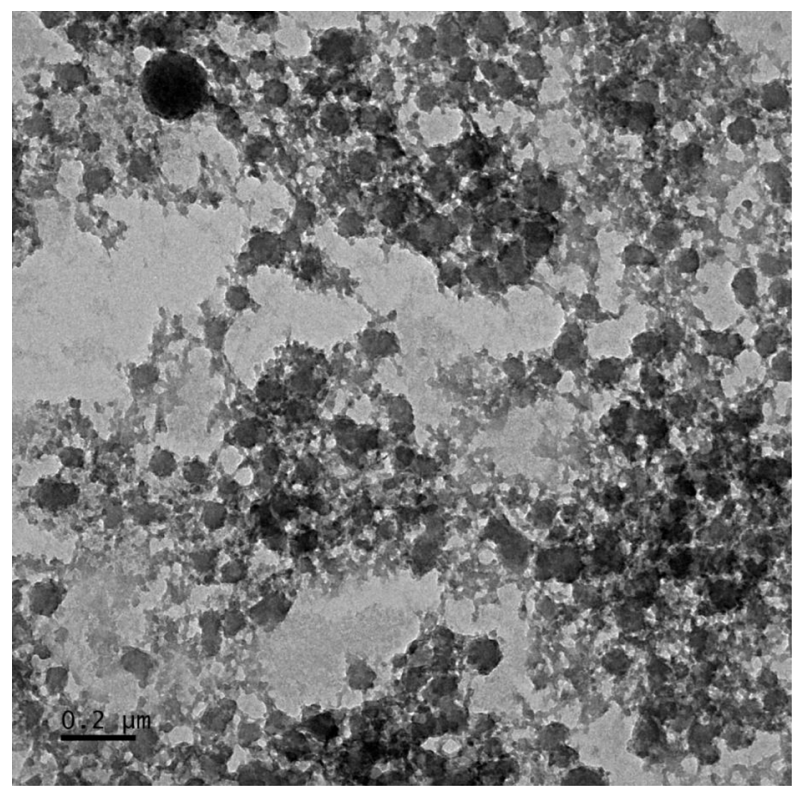

a

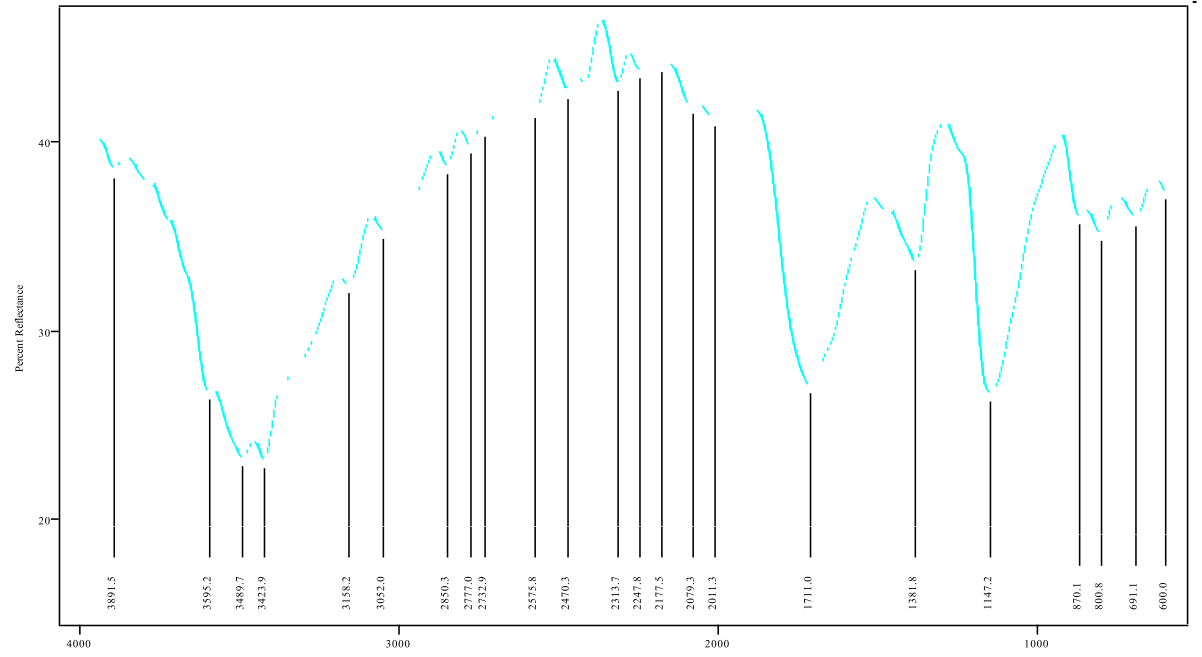

b

Fig. 1 a The TEM micrograph of biosynthesised CaNPs. b FTIR spectrum of calcium nanoparticles mediated with Cola nitida

A measure of $\mathrm{Na}$ influence (Table 1) on soil properties was significantly $(\mathrm{p}<0.05)$ restricted in $\mathrm{C}$ and $\mathrm{E}$. A significant decrease in exchangeable sodium percentage (ESP) and increase in $\mathrm{Ca}$ in the soil are an indication pointing to lower salinity of amended soils.

\subsection{Influence of CaNPs on M. oleifera germination parameters}

Germination indicators are quality metrics to gauge the importance of different concentrations of CaNPs and $\left(\mathrm{Ca}\left(\mathrm{NO}_{3}\right)_{2}\right)$ as compared with water (control) on modulation on tolerance ability of $M$. oleifera. Noteworthy variations with better physiological expressions in germination percentages, number of leaves, root and shoot lengths (Fig. 3) in M. oleifera planted on zero-charged CaNP-amended soil (C, D and E) in comparison with water $(\mathrm{A})$ and $\mathrm{Ca}\left(\mathrm{NO}_{3}\right)_{2}(\mathrm{~B})$ were observed.

Amendment with 75 and $100 \mathrm{mgL}^{-1}$ CaNPs significantly $(\mathrm{p}<0.05)$ increased shoot and root lengths with groups $\mathrm{B}$ $\left(\mathrm{Ca}\left(\mathrm{NO}_{3}\right)_{2}\right)$ and $\mathrm{E}\left(50 \mathrm{mgL}^{-1} \mathrm{CaNPs}\right)$ having comparable root and shoot lengths to $\mathrm{A}$ (control) (Table 3). The 75 $\mathrm{mgL}^{-1}$ CaNPs had 28.98 and $16.67 \%$ improvements in shoot and root lengths respectively while the $100 \mathrm{mgL}^{-1}$ CaNPs had enhanced shoot and root lengths with 42.69 
Table 1 Analysis of pre-planting and post-harvest soils with ICP-OES

\begin{tabular}{|c|c|c|c|c|c|c|}
\hline Soil characteristics & A & B & $\mathrm{C}$ & D & $E$ & $F$ \\
\hline$\overline{\mathrm{pH}}\left(\mathrm{H}_{2} \mathrm{O}\right)$ & $6.53 \pm 0.03^{a}$ & $6.67 \pm 0.07^{\mathrm{a}}$ & $6.62 \pm 0.02^{\mathrm{a}}$ & $6.62 \pm 0.04^{a}$ & $6.62 \pm 0.12^{\mathrm{a}}$ & $6.59 \pm 0.03^{a}$ \\
\hline Organic carbon (\%) & $454.28 \pm 14.27^{\mathrm{a}}$ & $442.50 \pm 22.16^{b}$ & $463.07 \pm 16.97^{c}$ & $453.86 \pm 42.06^{\mathrm{a}}$ & $447.14 \pm 39.66^{\mathrm{a}, \mathrm{b}}$ & $464.31 \pm 21.21^{c}$ \\
\hline Organic matter (\%) & $783.18 \pm 24.60^{a}$ & $762.83 \pm 30.23^{b}$ & $798.98 \pm 29.26^{c}$ & $782.17 \pm 72.51^{\mathrm{a}}$ & $770.89 \pm 68.37^{d}$ & $800.47 \pm 36.57^{c}$ \\
\hline Clay (\%) & $12.22 \pm 1.05^{\mathrm{a}}$ & $12.63 \pm 0.86^{\mathrm{a}}$ & $12.84 \pm 1.42^{\mathrm{a}}$ & $12.81 \pm 0.56^{\mathrm{a}}$ & $12.26 \pm 0.79^{a}$ & $12.85 \pm 1.37^{\mathrm{a}}$ \\
\hline Silt (\%) & $29.19 \pm 0.89^{a}$ & $29.29 \pm 0.04^{a}$ & $29.36 \pm 1.44^{a}$ & $29.40 \pm 0.84^{\mathrm{a}}$ & $29.23 \pm 0.66^{a}$ & $29.51 \pm 1.08^{\mathrm{a}}$ \\
\hline Sand (\%) & $58.59 \pm 0.95^{a}$ & $58.07 \pm 1.17^{\mathrm{a}}$ & $58.34 \pm 0.99^{a}$ & $57.79 \pm 0.27^{\mathrm{a}}$ & $58.66 \pm 1.12^{a}$ & $57.64 \pm 0.86^{a}$ \\
\hline CEC $\left(\mathrm{cmol}_{C} \mathrm{Kg}^{-1}\right)$ & $7.54 \pm 0.22^{\mathrm{a}}$ & $7.98 \pm 0.82^{b}$ & $8.39 \pm 0.76^{c}$ & $7.93 \pm 0.61^{b}$ & $8.01 \pm 0.67^{\mathrm{ab}}$ & $8.16 \pm 0.66^{b}$ \\
\hline$N\left(\mathrm{mgkg}^{-1}\right)$ & $544.18 \pm 7.14^{\mathrm{a}}$ & $573.33 \pm 6.99^{b}$ & $576.68 \pm 5.44^{b}$ & $568.32 \pm 4.06^{\mathrm{b}, \mathrm{c}}$ & $552.43 \pm 7.87^{c}$ & $540.31 \pm 6.32^{\mathrm{a}}$ \\
\hline$P\left(\mathrm{mgkg}^{-1}\right)$ & $13.45 \pm 0.55^{\mathrm{a}}$ & $12.95 \pm 0.15^{\mathrm{a}}$ & $13.94 \pm 0.88^{a}$ & $13.13 \pm 0.63^{\mathrm{a}}$ & $12.90 \pm 0.01^{\mathrm{a}}$ & $13.68 \pm 0.18^{\mathrm{a}}$ \\
\hline $\mathrm{K}\left(\mathrm{mgkg}^{-1}\right)$ & $91.20 \pm 0.03^{a}$ & $92.44 \pm 0.02^{a}$ & $93.07 \pm 0.07^{a}$ & $98.50 \pm 0.05^{b}$ & $96.68 \pm 0.72^{b}$ & $108.24 \pm 0.08^{c}$ \\
\hline $\mathrm{Na}\left(\mathrm{mgkg}^{-1}\right)$ & $16.21 \pm 0.05^{\mathrm{a}}$ & $18.97 \pm 1.07^{a, b}$ & $14.16 \pm 0.17^{c}$ & $17.57 \pm 0.07^{a, b}$ & $15.33 \pm 0.09^{\mathrm{a}}$ & $19.31 \pm 0.17^{\mathrm{b}}$ \\
\hline $\mathrm{Ca}\left(\mathrm{mgkg}^{-1}\right)$ & $38.09 \pm 0.01^{a}$ & $43.40 \pm 0.03^{b}$ & $44.18 \pm 0.00^{b}$ & $40.43 \pm 0.00^{\mathrm{a}, \mathrm{b}}$ & $41.17 \pm 0.02^{a, b}$ & $38.38 \pm 0.00^{a}$ \\
\hline $\mathrm{Mg}\left(\mathrm{mgkg}^{-1}\right)$ & $29.86 \pm 0.77^{\mathrm{a}}$ & $31.09 \pm 0.59^{\mathrm{a}}$ & $32.88 \pm 0.18^{a, b}$ & $34.21 \pm 0.22^{b}$ & $31.19 \pm 0.02^{a}$ & $34.23 \pm 0.07^{b}$ \\
\hline $\mathrm{Be}\left(\mathrm{mgkg}^{-1}\right)$ & nd & $0.0029 \pm 0.00^{\mathrm{a}}$ & $0.0008 \pm 0.00^{b}$ & $0.0021 \pm 0.00^{\mathrm{a}}$ & $0.0005 \pm 0.00^{b}$ & $0.0658 \pm 0.00^{c}$ \\
\hline $\mathrm{Fe}\left(\mathrm{mgkg}^{-1}\right)$ & $51.80 \pm 0.20^{\mathrm{a}}$ & $50.12 \pm 0.06^{\mathrm{a}}$ & $52.45 \pm 0.34^{\mathrm{a}}$ & $52.79 \pm 0.59^{a}$ & $51.12 \pm 0.24^{a}$ & $51.00 \pm 0.74^{a}$ \\
\hline $\mathrm{Mn}\left(\mathrm{mgkg}^{-1}\right)$ & $1.65 \pm 0.01^{a}$ & $1.62 \pm 0.00^{\mathrm{a}}$ & $1.63 \pm 0.01^{\mathrm{a}}$ & $1.29 \pm 0.02^{b}$ & $1.13 \pm 0.01^{c}$ & $1.67 \pm 0.01^{a}$ \\
\hline $\mathrm{Zn}\left(\mathrm{mgkg}^{-1}\right)$ & $1.30 \pm 0.00^{\mathrm{a}}$ & $1.45 \pm 0.00^{b}$ & $1.38 \pm 0.00^{a, b}$ & $1.58 \pm 0.00^{c}$ & $1.37 \pm 0.00^{a, b}$ & $1.77 \pm 0.01^{d}$ \\
\hline $\mathrm{Cu}\left(\mathrm{mgkg}^{-1}\right)$ & $1.23 \pm 0.02^{\mathrm{a}}$ & $1.47 \pm 0.00^{b}$ & $1.43 \pm 0.01^{b}$ & $1.93 \pm 0.37^{c}$ & $1.51 \pm 0.01^{b}$ & $1.94 \pm 0.54^{c}$ \\
\hline $\mathrm{Ni}\left(\mathrm{mgkg}^{-1}\right)$ & $0.038 \pm 0.00^{\mathrm{a}}$ & $0.035 \pm 0.00^{\mathrm{a}}$ & $0.017 \pm 0.00^{b}$ & $0.041 \pm 0.01^{\mathrm{a}, \mathrm{c}}$ & $0.024 \pm 0.00^{b}$ & $0.049 \pm 0.01^{c}$ \\
\hline $\mathrm{Cd}\left(\mathrm{mgkg}^{-1}\right)$ & $0.49 \pm 0.00^{a}$ & $0.108 \pm 0.00^{b}$ & $0.107 \pm 0.00^{b}$ & $0.108 \pm 0.00^{b}$ & $0.102 \pm 0.00^{b}$ & $0.69 \pm 0.00^{c}$ \\
\hline $\mathrm{Pb}\left(\mathrm{mgkg}^{-1}\right)$ & $0.25 \pm 0.01^{\mathrm{a}}$ & $0.21 \pm 0.01^{a, b}$ & $0.17 \pm 0.00^{b}$ & $0.18 \pm 0.00^{b}$ & $0.19 \pm 0.01^{b}$ & $0.32 \pm 0.01^{c}$ \\
\hline $\mathrm{Cr}\left(\mathrm{mgkg}^{-1}\right)$ & $0.18 \pm 0.00^{\mathrm{a}}$ & $0.15 \pm 0.01^{a}$ & $0.14 \pm 0.00^{\mathrm{a}}$ & $0.143 \pm 0.01^{b}$ & $0.127 \pm 0.01^{b}$ & $0.193 \pm 0.01^{c}$ \\
\hline As $\left(\mathrm{mgkg}^{-1}\right)$ & nd & $0.108 \pm 0.00^{\mathrm{a}}$ & nd & nd & $0.0030 \pm 0.00^{b}$ & $0.184 \pm 0.01^{c}$ \\
\hline $\operatorname{ESP}\left(\mathrm{cmol}_{\mathrm{C}} \mathrm{Kg}^{-1}\right)$ & $0.095 \pm 0.01^{\mathrm{a}, \mathrm{c}}$ & $0.103 \pm 0.01^{a}$ & $0.078 \pm 0.00^{b}$ & $0.094 \pm 0.00^{\mathrm{a}, \mathrm{c}}$ & $0.087 \pm 0.00^{c}$ & $0.100 \pm 0.00^{\mathrm{a}}$ \\
\hline
\end{tabular}

Group A: water (control), group B: $100 \mathrm{mg} \mathrm{Ca}\left(\mathrm{NO}_{3}\right)_{2} / \mathrm{kg}$ soil, group C: $100 \mathrm{mg} \mathrm{CaNPs} / \mathrm{kg}$ soil, group D: $75 \mathrm{mg} \mathrm{CaNPs} / \mathrm{kg}$ soil, group E: $50 \mathrm{mg}$ CaNPs/kg soil, F: preplanting (raw) soil. Results are expressed as mean \pm standard deviation of three replicates. Results having different superscripts across the rows are significantly different $(p<0.05)$. nd, not detected

and $35.09 \%$ respectively (Table 3 ). Percentage germination improved significantly $(\mathrm{p}<0.05)$ in $\mathrm{C}$ and $\mathrm{D}$ by 40.18 and $29.28 \%$ while marginal non-significant $(\mathrm{p}>$ $0.05)$ modulation was observed in B (8.91\%) and in $\mathrm{E}$ (4.31\%). Leaves (number) flourished significantly ( $\mathrm{p}<$ 0.05 ) better by $40.99 \%$ in C and $13.95 \%$ in D whereas B had a statistically comparable number of leaves to A except for $\mathrm{E}$ that had a slight decrease. Relative water contents were significantly $(\mathrm{p}<0.05)$ higher in $\mathrm{C}$ and $\mathrm{D}$ than $\mathrm{A}$ while $\mathrm{E}$ and $\mathrm{B}$ had comparable contents to A (Table 3). Vigour indices of groups B, C and D were significantly higher than $\mathrm{A}$ but $\mathrm{E}$ had a lower index than $\mathrm{A}$.

\subsection{Stimulatory influence of zero-charged CaNPs on carotenoid and total chlorophyll contents}

Total chlorophyll contents of $M$. oleifera planted on CaNPs were significantly improved (Table 3 ) compared to A. Group C had the highest chlorophyll a followed by group $\mathrm{D}$ and $\mathrm{E}$. The main photosynthetic pigment (chlorophyll a) was CaNP concentration-dependent.
Similarly, $\mathrm{Ca}\left(\mathrm{NO}_{3}\right)_{2}$ (group B) had significantly higher chlorophyll b than group A but chlorophyll a content was comparable even though lower by $14.38 \%$. Chlorophyll b contents follow groups $\mathrm{C}>\mathrm{B}>\mathrm{D}>\mathrm{E}>\mathrm{A}$.

The indicator of efficient photosynthetic activity (Fig. 4) was inverse-CaNP concentration-dependent. $\mathrm{Ca}\left(\mathrm{NO}_{3}\right)_{2}$ (B) was least efficient while $50 \mathrm{mgL}^{-1}$ was most efficient in boosting photosynthetic activities in M. oleifera.

Concentration-dependent stimulatory influences of CaNPs on carotenoid contents in M. oleifera (Table 3) are significantly $(\mathrm{p}<0.05)$ pronounced in groups $\mathrm{C}, \mathrm{D}$ and $E$ with group $B$ having insignificantly $(p>0.05)$ lower contents compared to group A.

\subsection{Impact of CaNPs on M. oleifera root mineral nutrient, heavy metal absorption and adsorption}

For macronutrients in roots (Table 4), concentrations of $\mathrm{Ca}$ and $\mathrm{Mg}$ were statistically significantly $(\mathrm{p}<0.05) \mathrm{im}$ proved in all CaNP-amended soils along with $\mathrm{K}$ in 

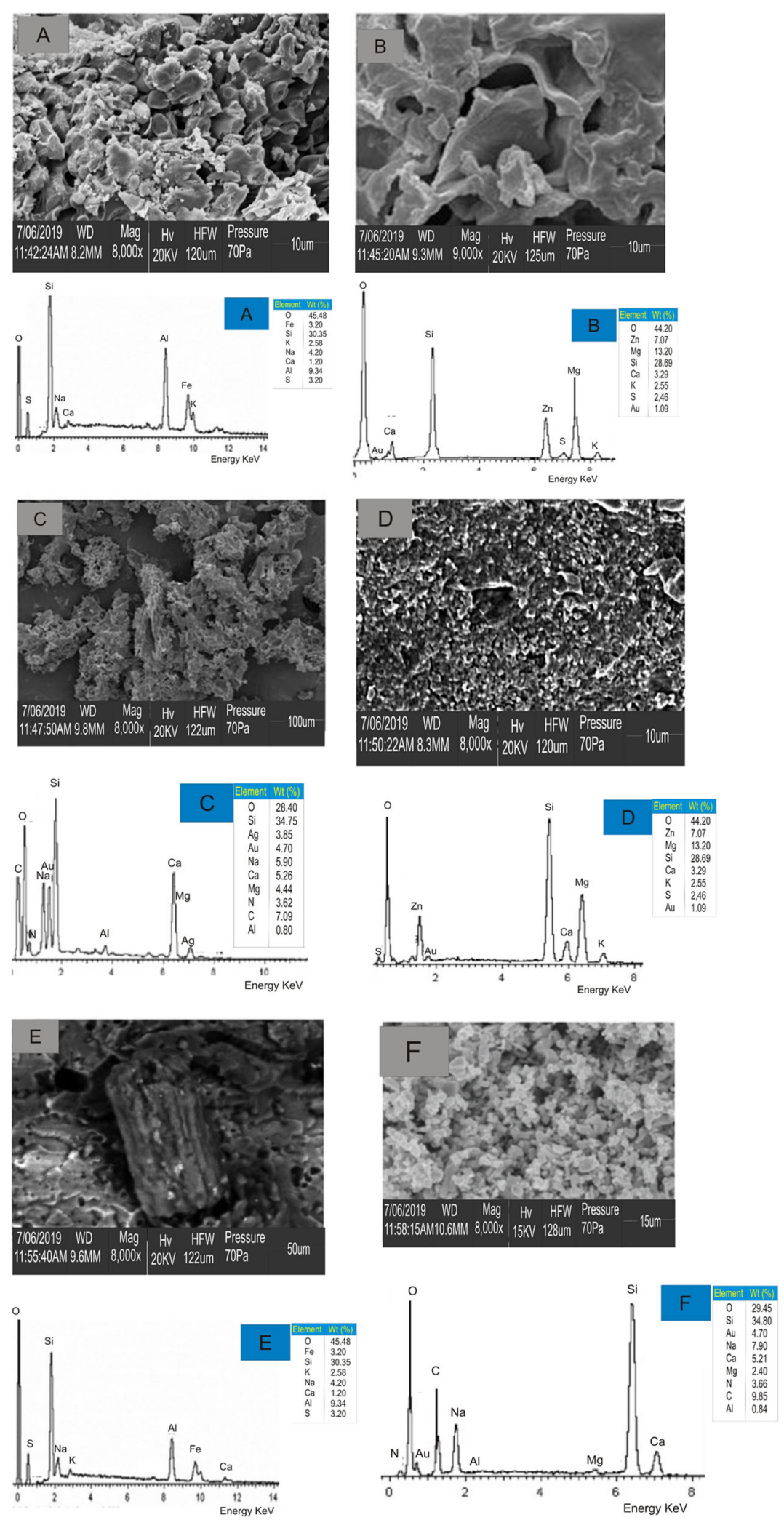

Fig. 2 SEM and EDX images of raw and amended soil samples. Group: A water (control), group B: 100 mg Ca(NO3)2/kg soil, group C: 100 mg CaNPs/kg soil, group D: 75 mg CaNPs/kg soil, group E: 50 mg CaNPs/kg soil, F- pre-planting (raw) soil 
Table 2 Elemental composition (Weight \%) of pre-planting and post-harvest soils using EDX

\begin{tabular}{lllllll}
\hline Elements & A & B & C & D & E & F \\
\hline $\mathrm{O}$ & 45.48 & 44.20 & 28.40 & 44.20 & 45.48 & 29.45 \\
$\mathrm{Si}$ & 30.35 & 28.69 & 34.70 & 28.69 & 30.35 & 34.80 \\
$\mathrm{Fe}$ & 3.20 & - & - & - & 3.20 & - \\
$\mathrm{K}$ & 2.58 & 2.55 & - & 2.55 & 2.58 & - \\
$\mathrm{Na}$ & 4.20 & - & 5.90 & - & 4.20 & 7.90 \\
$\mathrm{Ca}$ & 1.20 & 3.29 & 5.26 & 3.29 & 1.20 & 5.21 \\
$\mathrm{Al}$ & 9.34 & - & 0.8 & - & 9.34 & 0.84 \\
$\mathrm{~S}$ & 3.20 & 2.46 & - & 2.46 & 3.20 & - \\
$\mathrm{N}$ & - & - & 3.62 & - & - & 3.66 \\
$\mathrm{Zn}$ & - & 7.07 & - & 7.07 & - & - \\
$\mathrm{Mg}$ & - & 13.20 & 4.44 & 13.20 & - & 2.40 \\
$\mathrm{Ag}$ & - & - & 3.85 & - & - & - \\
$\mathrm{C}$ & - & - & 7.09 & - & - & 9.85 \\
$\mathrm{Au}$ & - & - & 4.70 & 1.09 & 4.70 & - \\
\hline
\end{tabular}

Group A: water (control), group B: $100 \mathrm{mg} \mathrm{Ca}\left(\mathrm{NO}_{3}\right)_{2} / \mathrm{kg}$ soil, group C: $100 \mathrm{mg}$ CaNPs/kg soil, group D: $75 \mathrm{mg}$ CaNPs/kg soil, group E: $50 \mathrm{mg}$ CaNPs/kg soil, F: pre-planting (raw) soil

groups D and E. Absorption of Na was significantly ( $\mathrm{p}<$ 0.05 ) suppressed in $\mathrm{C}, \mathrm{D}$ and $\mathrm{E}$ to the tune of 31.39, 15.26 and $19.94 \%$ respectively while an insignificant minimal reduction was obtained for $\mathrm{B}$.

Root absorption of macronutrients by M. oleifera from soil (Table 4) increased $\mathrm{K}$ by $1.23,3.03,0.48$ and $5.16 \%$ together with Ca by $0.12,1.53,5.30$ and $0.4 \%$ in $\mathrm{B}, \mathrm{C}, \mathrm{D}$ and $\mathrm{E}$ respectively over control (A). Percentage of $\mathrm{Mg}$ absorbed in root only increased in $\mathrm{C}$ and $\mathrm{E}$; others had decreased contents compared to A. Percentage of absorption of $\mathrm{Na}$ declined by 15.82, 21.23, 21.56 and 15.24 $\%$ in $\mathrm{B}, \mathrm{C}, \mathrm{D}$ and $\mathrm{E}$ in contrast to $\mathrm{A}$ (control).

Micronutrient concentrations (Table 4) follow the trend $\mathrm{Fe}>\mathrm{Zn}>\mathrm{Cu}>\mathrm{Mn}$ in $M$. oleifera planted on amended and control soil. Levels of $\mathrm{Fe}, \mathrm{Mn}$ and $\mathrm{Zn}$ absorbed by roots of $M$. oleifera increased significantly $(\mathrm{p}<0.05)$ in $\mathrm{B}$ and $\mathrm{C}$ alongside $\mathrm{Fe}$ in $\mathrm{E}$ and $\mathrm{Cu}$ in $\mathrm{C}$. Other groups had nearly similar concentrations compared to A (control). Percentage of $\mathrm{Mn}$ absorption in roots of $M$. oleifera improved by $12.93,13.97,24.92 \%$ in $\mathrm{B}, \mathrm{C}$ and $\mathrm{E}$ respectively followed by $\mathrm{Fe}$ by $3.84,9.02$, 6.47, $9.44 \%$ in B, C, D and E respectively then in $\mathrm{Zn}$ by 4.95 and $7.74 \%$ in $B$ and $C$ respectively in addition to Cu by $2.27 \%$ in $\mathrm{C}$ over $\mathrm{A}$.

Availability of heavy metals found in the roots of $M$. oleifera (Table 4) ranged as follows: $\mathrm{Pb}>\mathrm{Cd}>\mathrm{Cr}>\mathrm{Ni}$. Significant $(\mathrm{p}<0.05)$ reductions in contents of $\mathrm{Ni}$ in $\mathrm{C}$, $\mathrm{Pb}$ in $\mathrm{B}$ and $\mathrm{C}$ and $\mathrm{Cd}$ in $\mathrm{B}, \mathrm{C}, \mathrm{D}$ and $\mathrm{E}$ together with $\mathrm{Cr}$ in $\mathrm{E}$ were obtained. Arsenic (As) was not detected in all roots except in B. Percentage of $\mathrm{Cd}$ absorbed by $M$. oleifera roots (Table 4) decreased by 4.3, 16.28, 13.88 and $16.1 \%$ in $\mathrm{B}, \mathrm{C}, \mathrm{D}$ and $\mathrm{E}$ respectively and $\mathrm{Pb}$ by 4.02 , 13.76 and $7.49 \%$ in B, C and D respectively. Increased root absorption of $\mathrm{Ni}$ was found in all groups except for D. Likewise, $\mathrm{Cr}$ absorption increased in $\mathrm{B}$ and $\mathrm{D}$ although, a minimal reduction was found for $\mathrm{C}$ and $\mathrm{E}$. Except for B, As was not absorbed by roots.

Phytoremediation (immobilisation) percentages (Table 4) in $\mathrm{A}$ are 6.87 19.49, 21.71, 28.82, and 100 for $\mathrm{Cr}, \mathrm{Ni}$, $\mathrm{Pb}, \mathrm{Cd}$, and As respectively. Immobilisation percentages improved to $28.45,84.36,36.13,21.57 \%$ for $\mathrm{Ni}, \mathrm{Cd}, \mathrm{Pb}$, $\mathrm{Cr}$ although with reduced immobilisation of As by $\mathrm{Ca}\left(\mathrm{NO}_{3}\right)_{2}$ as compared to A. CaNPs further enhanced percentages immobilisation to $64.71,84.51,47.24,28.83$ and 100 in C; 17.14, 84.38, 46.03, 26.03 and 44.02 in D and 52.40, 85.31, 40.40, 34.07 and $98.37 \%$ in $\mathrm{E}$ for $\mathrm{Ni}$, $\mathrm{Cd}, \mathrm{Pb}, \mathrm{Cr}$ and As respectively.

\section{Discussion}

Vegetable production efficiency is directly associated with the potential contribution of soil nutrients. Insufficient harmonisation of soil nutrients occasioned by different agricultural practices has created a vacuum for the use of agrochemicals. Agrochemicals undoubtedly assist to replenish lost nutrients; however; ecological drawbacks and precipitation of ineffectual organo-minerals are some of their shortcomings [2, 4-9, 12, 15]. Moreover, metal nanoparticles as alternatives to agrochemicals acting as soil conditioners and plant growth enhancers have been reported in several studies $[1,9,16]$.

Our results indicate that soils amended with CaNPs were structurally stable having similar percentages of clay, silt and sand although were more porous and in some cases more crystalline that could aid translocation as well as absorption of nutrients. CaNPs altered significantly the morphologies of amended soil to increase porosity, improve soil surface reactivity, enhance water absorption, nutrient and CaNP translocation. Similar observations were recorded by $[50,51]$. Porosity is an influential factor that determines soil viability and productivity and has a direct association with water holding capacity (WHC). Water holding capacity of soil is one of the parameters of importance in plant growth sustenance [2, 51]. Originally, raw soil in this study was composed of low porous compact soil aggregate that changed significantly with the introduction of CaNPs. Nanoparticles are known to interact with soil by altering agglomeration and aggregation rates to facilitate soil/nanoparticles granules into easily transportable units through modification of surface charges $[7,46]$.

Soil chemical properties are quality indicators to determine the fertility, health and exchangeable cation abilities of soil [2]. Amended soils are slightly less acidic 

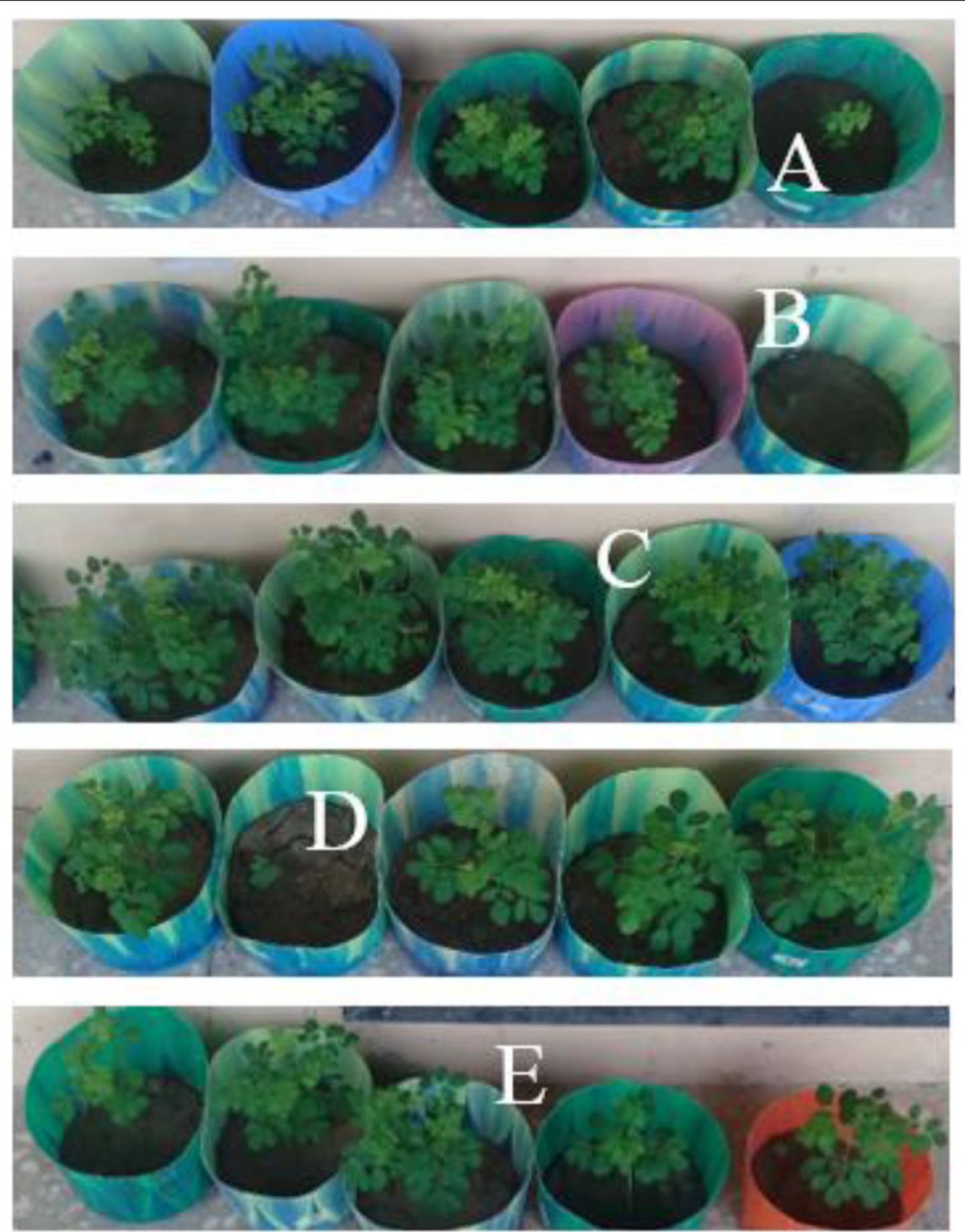

Fig. 3 Growth patterns of M. oleifera on raw and amended soil samples. Group A: water (control), group B: $100 \mathrm{mg} \mathrm{Ca(NO3)2/kg} \mathrm{soil,} \mathrm{group} \mathrm{C:}$ 100 mg CaNPs/kg soil, group D: 75 mg CaNPs/kg soil, group E: 50 mg CaNPs/kg soil, F- pre-planting (raw) soil

that might have resulted from amendment since the $\mathrm{pH}$ of CaNPs were higher. $\mathrm{pH}$ is a determining factor that affects soil nutrient availability, microbial processes and mobility of toxic trace elements $[23,52,53]$. Useful macronutrients such $\mathrm{K}, \mathrm{Ca}, \mathrm{N}, \mathrm{P}$ and some micronutrients like $\mathrm{S}, \mathrm{Cu}, \mathrm{Mn}, \mathrm{Fe}$ are usually more mobile between $\mathrm{pH}$ 6.5-7.5 especially with an increase in $\mathrm{pH}$ towards 7.5 whereas toxic trace metals mobility would be more retarded [7,46]. Nanoparticles have abilities to alter soil $\mathrm{pH}$ by changing concentrations of $\mathrm{H}^{+}$or $\mathrm{OH}^{-}$in soil pore water $[26,50,54]$. This implies that the slight increase in $\mathrm{pH}$ could have contributed to additionally available macronutrients obtained in this study and perhaps higher immobilisation of heavy metals.

Amended soils are as rich in organic matter and organic carbon as raw soil particularly amended soil with $100 \mathrm{mgL}^{-1}$ CaNPs though with higher CEC. Organic matter is the reservoir of soil fertility and consequentially influential in sustaining the soil ecosystem $[7,55]$. The largely unchanged compositions of organic matter by CaNPs amendment is connected to the lengthy period it would take for complete mineralisation of soil for a noticeable change in soil organic contents. This is in consonance with results of $[26,46,54,56]$ that 
Table 3 Germination and physiological indices of M. oleifera grown under different soil conditions

\begin{tabular}{|c|c|c|c|c|c|c|c|c|c|}
\hline \multirow[t]{2}{*}{ Groups } & \multirow[t]{2}{*}{$\begin{array}{l}\text { Root } \\
\text { length }\end{array}$} & \multirow[t]{2}{*}{$\begin{array}{l}\text { Shoot } \\
\text { length }\end{array}$} & \multirow[t]{2}{*}{$\begin{array}{l}\text { number of } \\
\text { leaves }\end{array}$} & \multirow[t]{2}{*}{$\begin{array}{l}\text { Vigour } \\
\text { index }\end{array}$} & \multirow[t]{2}{*}{$\begin{array}{l}\text { Percentage } \\
\text { germination }\end{array}$} & \multirow[t]{2}{*}{$\begin{array}{l}\text { Relative water } \\
\text { content }\end{array}$} & \multicolumn{3}{|c|}{$\begin{array}{l}\text { Photosynthetic pigments ( } \mathrm{mg} / \mathrm{g} \text { of } \\
\text { fresh weight) }\end{array}$} \\
\hline & & & & & & & $\begin{array}{l}\text { Chlorophyll } \\
\text { a }\end{array}$ & $\begin{array}{l}\text { Chlorophyll } \\
\text { b }\end{array}$ & Carotenoids \\
\hline $\bar{A}$ & $\begin{array}{l}3.42 \pm \\
0.16^{a}\end{array}$ & $\begin{array}{l}10.94 \pm \\
1.14^{\mathrm{a}}\end{array}$ & $41.86 \pm 2.51^{a}$ & $\begin{array}{l}826.28 \pm \\
7.18^{\mathrm{a}}\end{array}$ & $57.54 \pm 5.52^{a}$ & $36.77 \pm 0.65^{a, d}$ & $1.53 \pm 0.33^{a}$ & $1.35 \pm 0.92^{a}$ & $3.22 \pm 0.68^{a}$ \\
\hline B & $\begin{array}{l}3.38 \pm \\
0.06^{a}\end{array}$ & $\begin{array}{l}12.46 \pm \\
0.08^{\mathrm{b}, \mathrm{c}}\end{array}$ & $\underset{a, c}{45.57 \pm 1.48}$ & $\begin{array}{l}986.67 \pm \\
3.36^{\mathrm{b}}\end{array}$ & $62.29 \pm 4.17^{a}$ & $31.03 \pm 0.93^{\mathrm{a}}$ & $1.31 \pm 0.44^{\mathrm{a}}$ & $2.41 \pm 0.78^{b}$ & $3.03 \pm 0.23^{a}$ \\
\hline C & $\begin{array}{l}4.62 \pm \\
0.26^{b}\end{array}$ & $\begin{array}{l}15.61 \pm \\
1.51^{c}\end{array}$ & $59.02 \pm 3.12^{b}$ & $\begin{array}{l}1631.75 \pm \\
11.81^{c}\end{array}$ & $80.66 \pm 2.88^{c}$ & $63.60 \pm 04.72^{b}$ & $4.45 \pm 0.35^{c}$ & $3.66 \pm 0.03^{c}$ & $6.07 \pm 0.47^{b}$ \\
\hline D & $\begin{array}{l}3.99 \pm \\
0.43^{c}\end{array}$ & $\begin{array}{l}14.11 \pm \\
1.21^{c}\end{array}$ & $47.71 \pm 0.82^{c}$ & $\begin{array}{l}1319.68 \pm \\
2.15^{d}\end{array}$ & $74.39 \pm 1.33^{d}$ & $58.49 \pm 6.32^{c}$ & $3.24 \pm 0.09^{b}$ & $2.20 \pm 0.19^{b}$ & $4.98 \pm 0.32^{c}$ \\
\hline E & $\begin{array}{l}3.63 \pm \\
0.39^{\mathrm{a}}\end{array}$ & $\begin{array}{l}10.66 \pm \\
0.03^{a}\end{array}$ & $40.43 \pm 2.89^{a}$ & $\begin{array}{l}819.27 \pm \\
1.75^{a}\end{array}$ & $60.02 \pm 4.28^{a}$ & $39.03 \pm 3.33^{d}$ & $2.42 \pm 0.22^{c}$ & $1.59 \pm 0.25^{a}$ & $4.18 \pm 0.82^{d}$ \\
\hline
\end{tabular}

Group A: water (control), group B: $100 \mathrm{mg} \mathrm{Ca}\left(\mathrm{NO}_{3}\right)_{2} / \mathrm{kg}$ soil, group C: $100 \mathrm{mg}$ CaNPs/kg soil, group D: $75 \mathrm{mg}$ CaNPs/kg soil, group E: $50 \mathrm{mg}$ CaNPs/kg soil. Results of percentage germination, root length, shoot length, relative water contents, vigour index and growth tolerance index are expressed as mean \pm standard deviation of fourteen replicates while number of leaves was expressed as mean \pm standard deviation of leaves on fourteen replicates. Results having different superscripts along the column are significantly different $(p<0.05)$

reported unchanged composition of organic matter following the addition of $\mathrm{CuO}$ and $\mathrm{Fe}_{3} \mathrm{O}_{4}$ nanoparticles but contrary results were reported by [51]. Nanoparticles are known to interpose within soil organic matter and clay to form aggregates that can easily be transported. Nanoparticle mobility is predicted by dispersibility and electrostatic attraction/repulsion between soil and charges on nanoparticles. There would be repulsion between negative soil surface charges and negative surfaces of CaNPs $\left(\mathrm{pH}_{\mathrm{pzc}}\right.$ value), thus increasing the mobility of CaNPs into plants. Hence, the closer the difference between soil $\mathrm{pH}$ and $\mathrm{pH}_{\mathrm{pzc}}$ of nanoparticles, the more mobile the nanoparticles are into plant roots. Also, the more porous the soil is, the less retained the nanoparticles are $[50,56]$. This is in agreement with the results of soil porosity as obtained in this study indicating CaNPs were most mobile in soil amended with $100 \mathrm{mgL}^{-1}$ CaNPs. This agrees with reports of $[24,50,51]$. Furthermore, higher CEC in soil amended with $100 \mathrm{mgL}^{-1}$ CaNPs suggests a highly reactive and more negatively charged soil $[1,2,51,57]$. CEC provides soil fertility status vis-à-vis its nutrient retention. As obtained in this study, it is clear that $100 \mathrm{mgL}^{-1}$ CaNPs improved soil ability to adsorb more nutrients and by extension an indication of soil quality and productivity $[2,46,51]$.

Amended soils are beneficially richer in nitrogen than raw. The improvement in $\mathrm{N}$ content might be credited to the release of nitrogen from CaNPs (mediated by the pod extract of $C$. nitida using $\mathrm{Ca}\left(\mathrm{NO}_{3}\right)_{2}$ salt) and nutrient mobilisation by the nanoparticles through enhancing

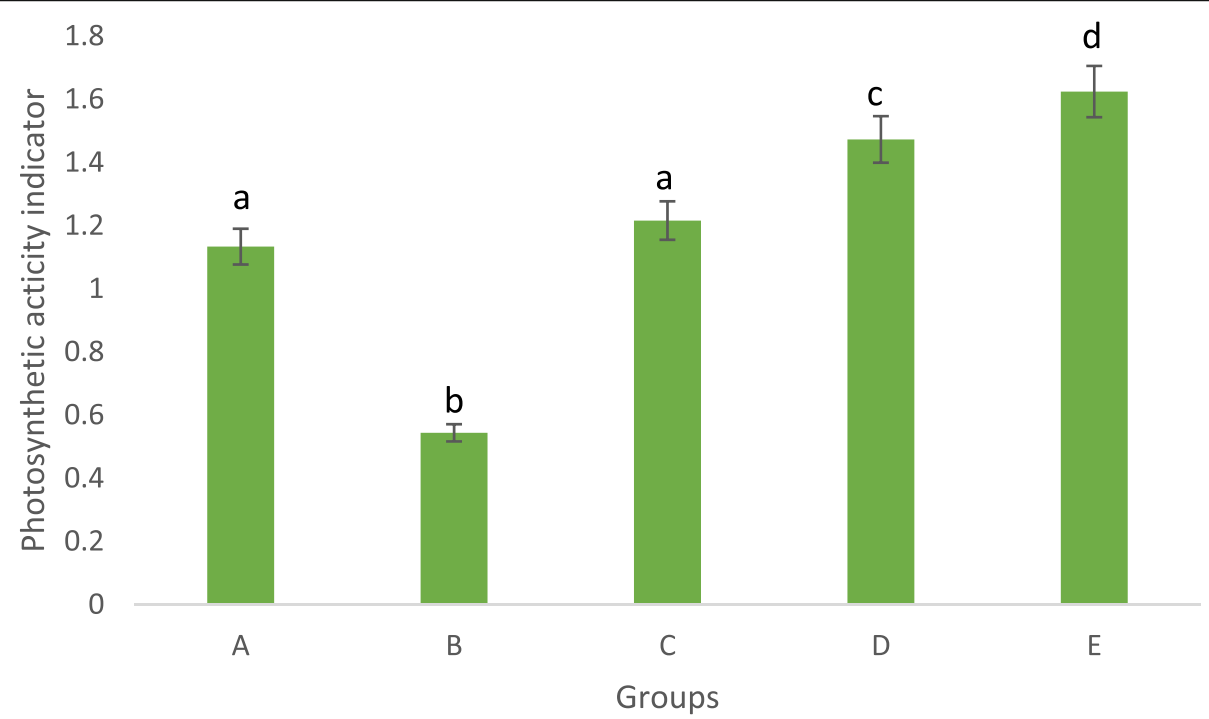

Fig. 4 Indicator of photosynthetic ability. Group: A water (control), group B: 100 mg Ca(NO3)2/kg soil, group C: 100 mg CaNPs/kg soil, group D: $75 \mathrm{mg}$ CaNPs/kg soil, group E: $50 \mathrm{mg}$ CaNPs/kg soil. Bars having different superscripts are significantly different $(p<0.05)$ 
Table 4 Mineral element constituents $\left(\mathrm{mgkg}^{-1}\right)$ in roots percentage absorption and immobilisation of heavy metal in $M$. oleifera, planted on $\mathrm{Ca}\left(\mathrm{NO}_{3}\right)_{2}$ and CaNP-amended soil

\begin{tabular}{|c|c|c|c|c|c|c|c|c|c|c|c|c|c|c|c|}
\hline \multirow[t]{2}{*}{ Metals } & \multicolumn{5}{|c|}{ Metal concentration in Root } & \multicolumn{5}{|c|}{ Percentage absorption } & \multicolumn{5}{|c|}{ Percentage immobilisation } \\
\hline & $\mathrm{A}$ & B & $\mathrm{C}$ & D & $E$ & $A$ & B & $\mathrm{C}$ & D & $\mathrm{E}$ & $A$ & B & C & D & $\mathrm{E}$ \\
\hline $\mathrm{K}$ & $\begin{array}{l}79.39 \pm \\
8.41^{a}\end{array}$ & $\begin{array}{l}82.49 \pm \\
0.00^{\mathrm{a}}\end{array}$ & $\begin{array}{l}83.23 \pm \\
3.23^{\mathrm{a}, \mathrm{b}}\end{array}$ & $\begin{array}{l}86.18 \pm \\
2.14^{\mathrm{b}, \mathrm{c}}\end{array}$ & $\begin{array}{l}89.16 \pm \\
1.14^{c}\end{array}$ & 87.05 & 88.28 & 90.41 & 87.52 & 92.21 & & & & & \\
\hline $\mathrm{Na}$ & $\begin{array}{l}16.05 \pm \\
0.59^{a}\end{array}$ & $\begin{array}{l}15.95 \pm \\
0.25^{a, c}\end{array}$ & $\begin{array}{l}11.02 \pm \\
0.42^{\mathrm{b}}\end{array}$ & $\begin{array}{l}13.60 \pm \\
0.66^{c}\end{array}$ & $\begin{array}{l}12.85 \pm \\
0.40^{\mathrm{b}}\end{array}$ & 99.09 & 84.08 & 77.86 & 77.42 & 83.85 & & & & & \\
\hline $\mathrm{Ca}$ & $\begin{array}{l}34.11 \pm \\
3.23^{\mathrm{a}}\end{array}$ & $\begin{array}{l}38.94 \pm \\
1.99^{\mathrm{b}}\end{array}$ & $\begin{array}{l}40.25 \pm \\
2.91^{b}\end{array}$ & $\begin{array}{l}39.16 \pm \\
2.33^{b}\end{array}$ & $\begin{array}{l}37.03 \pm \\
0.07^{a, b}\end{array}$ & 89.56 & 89.72 & 91.09 & 96.86 & 89.96 & & & & & \\
\hline $\mathrm{Mg}$ & $23.22 \pm 3.52$ & $\begin{array}{l}22.90 \pm \\
0.99^{\mathrm{a}}\end{array}$ & $28.83 \pm 7.16$ & $24.08 \pm 1.58$ & $\begin{array}{l}25.71 \pm \\
1.61^{a, b}\end{array}$ & 77.77 & 73.87 & 87.68 & 70.38 & 82.41 & & & & & \\
\hline $\mathrm{Fe}$ & $\begin{array}{l}28.40 \pm \\
6.06^{\mathrm{a}}\end{array}$ & $\begin{array}{l}30.39 \pm \\
8.17^{\mathrm{b}}\end{array}$ & $\begin{array}{l}34.54 \pm \\
7.74^{\mathrm{b}}\end{array}$ & $\begin{array}{l}32.36 \pm \\
2.68^{\mathrm{a}}\end{array}$ & $\begin{array}{l}33.87 \pm \\
9.95^{\mathrm{b}}\end{array}$ & 54.82 & 60.64 & 65.84 & 61.29 & 66.26 & & & & & \\
\hline $\mathrm{Mn}$ & $\begin{array}{l}0.72 \pm \\
0.01^{1, b}\end{array}$ & $0.91 \pm 0.00$ & $0.93 \pm 0.01$ & $0.502 \pm 0.02$ & $\begin{array}{l}0.77 \pm \\
0.01^{a, b}\end{array}$ & 43.09 & 56.02 & 57.06 & 38.96 & 68.01 & & & & & \\
\hline $\mathrm{Zn}$ & $1.19 \pm 0.00^{a}$ & $1.34 \pm 0.00$ & $1.37 \pm 0.00$ & $1.35 \pm 0.00$ & $1.12 \pm 0.00^{a}$ & 92.13 & 97.08 & 98.84 & 83.02 & 81.52 & & & & & \\
\hline $\mathrm{Cu}$ & $1.09 \pm 0.02^{a}$ & $0.97 \pm 0.00^{a}$ & $\frac{1.30 \pm 0.01}{b}$ & $0.94 \pm 0.01^{a}$ & $0.78 \pm 0.02^{c}$ & 88.55 & 66.08 & 90.84 & 49.01 & 51.62 & & & & & \\
\hline $\mathrm{Ni}$ & $\begin{array}{l}0.0223 \pm \\
0.01^{a}\end{array}$ & $\begin{array}{l}0.0203 \pm \\
0.01^{\mathrm{a}}\end{array}$ & $\begin{array}{l}0.015 \pm \\
0.01^{\mathrm{b}}\end{array}$ & $\begin{array}{l}0.018 \pm \\
0.01^{\mathrm{a}, \mathrm{b}}\end{array}$ & $0.02 \pm 0.00^{\mathrm{a}}$ & 56.03 & 57.36 & 85.61 & 43.07 & 83.50 & 19.49 & 28.45 & 64.71 & 17.14 & 52.40 \\
\hline $\mathrm{Cd}$ & $\begin{array}{l}0.102 \pm \\
0.00^{\mathrm{a}}\end{array}$ & $\underset{b}{b} .018 \pm 0.00$ & ${ }_{c}^{0.005 \pm 0.00}$ & $\underset{c}{0.007 \pm 0.00}$ & $\begin{array}{l}0.005 \pm \\
0.00^{c}\end{array}$ & 20.75 & 16.45 & 4.47 & 6.87 & 4.65 & 28.82 & 84.36 & 84.51 & 84.38 & 85.31 \\
\hline $\mathrm{Pb}$ & $0.19 \pm 0.01^{\mathrm{a}}$ & $\underset{b}{b} .103 \pm 0.01$ & $\begin{array}{l}0.107 \pm 0.00 \\
b\end{array}$ & $0.15 \pm 0.00^{a}$ & $0.16 \pm 0.00^{a}$ & 73.09 & 69.07 & 59.33 & 65.60 & 82.48 & 21.71 & 36.13 & 47.24 & 46.03 & 40.40 \\
\hline $\mathrm{Cr}$ & $\begin{array}{l}0.027 \pm \\
0.00^{\mathrm{a}}\end{array}$ & $\begin{array}{l}0.027 \pm \\
0.00^{\mathrm{a}}\end{array}$ & $\begin{array}{l}0.021 \pm \\
0.00^{\mathrm{a}, \mathrm{b}}\end{array}$ & $\begin{array}{l}0.022 \pm \\
0.00^{\mathrm{a}, \mathrm{b}}\end{array}$ & $\begin{array}{l}0.018 \pm \\
0.00^{\mathrm{b}}\end{array}$ & 14.85 & 17.47 & 14.64 & 15.61 & 14.02 & 6.87 & 21.57 & 28.83 & 26.03 & 34.07 \\
\hline As & nd & $\begin{array}{l}0.0020 \pm \\
0.00\end{array}$ & nd & nd & nd & 0 & 12.66 & 0 & 0 & 0 & 100 & 14.13 & 100 & 100 & 100 \\
\hline
\end{tabular}

Group A: water (control), group B: $100 \mathrm{mg} \mathrm{Ca}\left(\mathrm{NO}_{3}\right)_{2} / \mathrm{kg}$ soil, group C: $100 \mathrm{mg} \mathrm{CaNPs/kg} \mathrm{soil,} \mathrm{group} \mathrm{D:} 75 \mathrm{mg} \mathrm{CaNPs/kg} \mathrm{soil,} \mathrm{group} \mathrm{E:} 50 \mathrm{mg}$ CaNPs/kg soil. Results of mineral elements in roots and shoot are expressed as mean \pm standard deviation of three replicates. Results having different superscripts across the rows for each parameter are significantly different $(p<0.05)$. nd, not detected

microbial activities in soil. $\mathrm{Ca}_{3}\left(\mathrm{PO}_{4}\right)_{2}$ nanoparticles had similar nutrient-mobilising effects on rice. This has also been found in soil amended with $\mathrm{ZnO}, \mathrm{CuO}$ and $\mathrm{TiO}_{2}$ nanoparticles [2, 17, 26, 40,51]. A significant decrease in exchangeable sodium percentage (ESP) and an increase in Ca in soil imply lower salinity of amended soils. Salinity reduces plant growth, creates an imbalance in soilwater, disrupts plant cell functions and induces metabolic disorders in plants. Nanoparticles such as nitric oxide are reportedly efficient in reducing salinity, and similarly, $\mathrm{Ca}$ is known to regulate the salinity of soil $[3$, 40, 58-60]. Correspondingly, CaNPs would be efficiently better as a soil conditioner to reduce salinity stress and provide essential minerals by maintaining $\mathrm{K}$ concentration.

Availability of macro- and micronutrients such as $\mathrm{Ca}$, $\mathrm{N}$ and $\mathrm{Fe}$ in amended soil was higher than in raw whereas the presence of toxic heavy metals was consequently immobilised. These could be ascribed to CaNP amendment as nanoparticles are known to improve uptake of other beneficial nutrients [40]. Interestingly, as observed in EDX results, there was a mobilisation of $\mathrm{Ag}^{+}$ by $100 \mathrm{mgL}^{-1}$ CaNPs supporting possible antimicrobial potential against soil pathogens.

Germination parameters are indices to measure plant sensitivity to harsh environmental conditions, exposure to toxin and disturbance by pathogens [1, 3, 51]. Amendment with CaNPs promoted longer roots and shoots for absorption and translocation of nutrients for better M. oleifera yields. CaNPs hastened seed germination as observed in germination percentage by ensuring seed viability in soil and increased the number of leaves as well as vigour index to improve physiological tolerance against adverse environmental disorderliness. Vigour index can be used to access stimulatory and toxicity effects on seed germination $[8,12,22,25,35]$. It gives information about seed viability and its tolerance to toxicity; thus, significantly higher vigour indices recorded for M. oleifera planted on CaNP-amended soil (100 and $75 \mathrm{mgL}^{-1}$ ) indicate the stimulatory abilities of higher concentrations to influence seed germination and strengthening their physiological tolerance through 
better activations of biological enzymes required for seed viability [22, 23]. Relative water contents reflect water tolerance status in plants against drought. It indicates the balance between water absorption from soil and consumption via transpiration. It is well known that nanoparticles increase plant water permeability [13, 17]. Higher relative water contents in $M$. oleifera grown on 100 and $75 \mathrm{mgL}^{-1}$ CaNPs imply M. oleifera was more resistant against drought. These improvements in germination parameters are indications of cell promotion activities of CaNPs. This agrees with previous results of $[1,3,8,12$, 35, 60-64]. $\mathrm{Ca}_{3}\left(\mathrm{PO}_{4}\right)_{2}$ nanoparticles similarly had a positive influence on roots, shoot lengths and some antioxidant enzymes [40]. Interaction of CaNPs with cellular components of $M$. oleifera could have resulted in improved germination as previously reported by [1].

Conversely, $\mathrm{Ca}\left(\mathrm{NO}_{3}\right)_{2}$-amended soil considerably reduced relative water contents possibly resulting from clogging of root pores which might be signals of cytotoxicity induced by it without providing any alleviation [13]. This was also noted by [35] that $\mathrm{AgNO}_{3}$ salt solution was cytotoxic and led to a significant reduction in tomato root and shoot lengths but its nanoparticle counterpart had positive effects on these parameters.

Photosynthetic pigment contents are an expression of healthy functions of plants while carotenoids act as cellular redox buffer $[1,51,65]$. Improvements in their contents in M. oleifera planted on CaNP-amended soil is an attestation to enhanced enzyme activities responsible for photosynthetic mechanisms. Equally attributable to increased absorption and translocation of mineral nutrients (Fe and $\mathrm{Mg}$ ) involved in chlorophyll formation [13, 24]. The increase was concentration-dependent. However, $\mathrm{Ca}\left(\mathrm{NO}_{3}\right)_{2}$ reduced carotenoid contents but had nearly similar chlorophyll contents as control. This might be ascribed to disruption in enzyme activities and water absorption capacity as noted in phytochemical and relative water contents $[8,22]$. Indicator photosynthetic efficiency of CaNPs increased with decreasing concentration denoting that photosynthetic activities improved with decreasing concentration. Contrarily, $\mathrm{Ca}\left(\mathrm{NO}_{3}\right)_{2}$ inhibited these activities of chlorophyll by significantly reducing this ratio [13]. Carotenoids contribute to antioxidant activity; thus, its reduced content in M. oleifera planted on $\mathrm{Ca}\left(\mathrm{NO}_{3}\right)_{2}$ amended soil is an indication of reduced ability to protect against free radicals which were reported for percentage antioxidant activity. The positive influence of nanoparticles on chlorophyll pigments and carotenoids has been previously reported [1, $8,12,13]$.

Macro- and microelements are essential nutrients for various activities in plant tissues. Their presence is significantly correlated with the nutritional quality of plants. The increase in absorption and translocation rates of $\mathrm{K}, \mathrm{Ca}, \mathrm{Fe}, \mathrm{Mg}, \mathrm{Zn}$ and $\mathrm{Cu}$ obtained in this study suggest $M$. oleifera planted on amended soil are better sources of these nutrients for human consumption [43]. This is in addition to higher immobilisation rates of heavy metals. $\mathrm{Ca}, \mathrm{Mg}, \mathrm{Fe}, \mathrm{Zn}$ and $\mathrm{Mn}$ play prominent roles in bone development, glucose absorption, and regulation of blood and act as co-factors for enzymes. They play vital roles in the cation exchange capacity of roots leading to more absorption of essential nutrients such as $\mathrm{N}$ that may contribute to higher protein contents in plant parts $[26,38,64] . \mathrm{Ca}_{3}\left(\mathrm{PO}_{4}\right)_{2}$ nanoparticles have been reported to control pathogen infestation of Zizyphus mauritiana and Citrus tankan and assisted in the uptake of minerals that are required for metabolic activities in plants $[7,40,58,60]$. Improvements in mineral contents in $M$. oleifera by CaNPs imply that CaNPs can act as nano-fertilisers to enhance upward translocation of minerals to plants as it has been previously recorded that nanoparticles led to increased contents of these minerals in plants $[1,13,14,32,36,66,67]$. Additionally, large surface area and high penetration potentials of macronutrient nanofertilisers ensure efficiency in the delivery of nutrients to plant as have been demonstrated in studies reported for hydroxyapatite (P), nanoenabled urea $(\mathrm{N})$ and $\mathrm{Ca}\left(\mathrm{PO}_{4}\right)_{2}(\mathrm{Ca}, \mathrm{P})$ nanoparticles with improved macronutrient quantities in plant and enhanced plant metabolisms $[1,39,40]$.

Heavy metals such as $\mathrm{Cd}, \mathrm{Cr}, \mathrm{Pb}$ and As do not have known biological values and are extremely toxic [25]. The presence of heavy metals in M. oleifera planted on CaNP-amended soil greatly reduced with total immobilisation of As. This might be ascribed to the surface charges of CaNPs $\left(\mathrm{pH}_{\mathrm{pzc}}\right)$ and soil $\mathrm{pH}$. The $\mathrm{pH}_{\mathrm{pzc}}$ of CaNPs was lower than soil $\mathrm{pH}\left(\mathrm{pH}_{\mathrm{pzc}}<\mathrm{pH}\right)$, therefore would be anionic and would be available for adsorption of cations. Results of immobilisation of heavy metals with CaNPs in this study are consistent with previously reported results of metal nanoparticles by $[8,46,68]$. Nanoparticles have good adsorption capacities stemming from their morphology, surface charge, reactivity and size. Hence, their addition to soil was expected to improve the phytoremediation potential of M. oleifera and the adsorption capacity of the soil.

\section{Conclusion}

This study has reported the interplay between the application of CaNPs, soil fertility and modulatory influence on $M$. oleifera. CaNPs enlarged soil pores, improved soil fertility by increasing nitrogen contents and cation exchange capacity with a concomitant reduction in $\mathrm{Na}$ activities. Remarkable improvements in both macro- and micronutrient levels and immobilisation of heavy metals were recorded. Considerable promotions in growth parameters, physiological tolerance, higher translocation 
rates of essential nutrients and better indicators of efficiency of photosynthetic activities are confirmations of the phytomodulatory abilities of CaNPs.

\section{Abbreviations}

A: Group A (water); B: $100 \mathrm{mg} \mathrm{Ca}\left(\mathrm{NO}_{3}\right)_{2} / \mathrm{kg}$ soil (group B); C: $100 \mathrm{mg} \mathrm{CaNPs} /$ kg soil (group C); CEC: Cation exchange capacity; CaNPs: Calcium nanoparticles; D: 75 mg CaNPs/kg soil (group D); E: 50 mg CaNPs/kg soil (group E); ESP: Exchangeable sodium percentage; ICP-OES: Inductively coupled plasma with optical emission spectrometer; M. oleifera: Moringa oleifera; pHpzc: pH point of zero charge; SEM-EDX: Scanning electron microscope-energy dispersive $\mathrm{x}$-ray

\section{Acknowledgements}

Not applicable

\section{Declarations}

\section{Authors' contributions}

LA synthesised and characterised calcium nanoparticles using the pod extract of C. nitida. AL coordinated the planting, soil analysis and manuscript write-up. ARA and AAE handled elemental analysis. All authors have read and approved the manuscript

\section{Funding}

Not applicable

\section{Availability of data and materials}

All data and other supplementary materials are already included in the main manuscript

\section{Competing interest}

The authors declare no conflicts of interest in this study.

\section{Ethics approval and consent to participate}

Not applicable

\section{Consent for publication}

Not applicable

\section{Author details}

'Department of Pure and Applied Chemistry, Osun State University, Osogbo, Nigeria. ${ }^{2}$ Nanotechnology Research Group (NANO+), Laboratory of Industrial Microbiology and Nanobiotechnology, Department of Pure and Applied Biology, Ladoke Akintola University of Technology, Ogbomoso PMB 4000, Nigeria. ${ }^{3}$ Department of Chemistry, Adeleke University, Ede, Osun State, Nigeria.

Received: 2 March 2020 Accepted: 11 June 2021

Published online: 30 June 2021

\section{References}

1. Adisa IO, Pullagurala VLR, Peralta-Videa JR, Dimkpa CO, Elmer WH, GardeaTorresdey JL, White JC (2019) Recent advances in nano-enabled fertilizers and pesticides: a critical review of mechanisms of action. Environ Sci: Nano 6:2002-2030

2. Mukhopadhyay S, Masto RE, Tripathi RC, Srivastava NK (2019) Application of Soil Quality Indicators for the Phytorestoration of Mine Spoil Dumps. Phytomanag Poll Sites:361-388. https://doi.org/10.1016/B978-0-12-813912-7. 00014-4

3. Ren Y, Wang W, He J, Zhang L, Wei Y, Yang M (2020) Nitric oxide alleviates salt stress in seed germination and early seedling growth of pakchoi (Brassica chinensis L.) by enhancing physiological and biochemical parameters. Ecotoxicol Environ Saf 187:109785

4. Milewska-Hendel A, Zubko M, Karcz J, Stróz D, Kurczynska E (2017) Fate of neutral charged gold nanoparticles in the roots of the Hordeum vulgare L. cultivar Karat. Sci Rep 7:3014

5. Cunningham FJ, Goh NS, Demirer GS, Matos JL, Landry MP (2018) Nanoparticle mediated delivery towards advancing plant genetic engineering. Trends Biotechnol 36(9):882-897. https://doi.org/10.1016/j. tibtech.2018.03.009

6. White JC, Gardea-Torresdey JL (2018) Achieving food security through the very small. Nat Nanotechnol 13:621-629

7. Achari GA, Kowshik M (2018) Recent Developments on Nanotechnology in Agriculture: Plant Mineral Nutrition, Health, and Interactions with Soil Microflora. J Agric Food Chem 66(33):8647-8661. https://doi.org/10.1021/a cs.jafc.8b00691

8. Azeez L, Adejumo AL, Lateef A, Adebisi SA, Adetoro RO, Adewuyi S, Tijani KO, Olaoye S (2019) Zero-valent silver nanoparticles attenuate $\mathrm{Cd}$ and Pb toxicities on Moringa oleifera via immobilization and induction of phytochemicals. Plant Physiol Biochem 139:283-292. https://doi.org/10.101 6/j.plaphy.2019.03.030

9. Sanzari I, Leone A (2019) Ambrosone A. Nanotechnology in Plant Science: To Make a long story short. Front Bioeng Biotechnol 7:120

10. Dan Y, Zhang W, Xue R, Ma X, Stephan C, Shi H (2015) Characterization of gold nanoparticle uptake by tomato plants using enzymatic extraction followed by single particle inductively coupled plasma-mass spectrometry analysis. Environ Sci Technol 49(5):3007-3014. https://doi.org/10.1021/ es506179e

11. Liu R, Lal R (2015) Potentials of engineered nanoparticles as fertilizers for increasing agronomic productions. Sci Total Environ 514:131-139. https:// doi.org/10.1016/j.scitotenv.2015.01.104

12. Azeez L, Lateef A, Wahab AA, Rufai MA, Salau AK, Ajayi ElO, Ajayi M, Adegbite MK, Adebisi B (2019) Phytomodulatory effects of silver nanoparticles on Corchorus olitorius: Its antiphytopathogenic and hepatoprotective potentials. Plant Physiol Biochem 139:109-117

13. Tombuloglu H, Slimani Y, Tombuloglu G, Demir-Korkmaz A, Baykal A, Almessiere M, Ercan I (2019) Impact of superparamagnetic iron oxide nanoparticles (SPIONs) and ionic iron on physiology of summer squash (Cucurbita pepo): a comparative study. Plant Physiol Biochem 139:56-65. https://doi.org/10.1016/.jplaphy.2019.03.011

14. Tombuloglu H, Slimani Y, Tombuloglu G, Almessiere A, Demir-Korkmaz HSA, AlShammari TM, Baykal A, Ercan I, Hakeem KR (2019) Impact of calcium and magnesium substituted strontium nano-hexaferrite on mineral uptake, magnetic character, and physiology of barley (Hordeum vulgare L.). Ecotoxicol Environ Saf 186:109751

15. Azeez L, Lateef A, Adebisi SA (2017) Silver nanoparticles (AgNPs) biosynthesized using pod extract of Cola nitida enhances antioxidant activity and phytochemical composition of Amaranthus caudatus Linn. Appl Nanosci 7(1-2):59-66. https://doi.org/10.1007/s13204-017-0546-2

16. Juárez-Maldonado A, Ortega-Ortíz H, Morales-Díaz AB, González-Morales S, Morelos-Moreno A, Cabrera-De la Fuente M, Sandoval-Rangel A, CadenasPliego G, Benavides-Mendoza A (2019) Nanoparticles and nanomaterials as plant biostimulants. Int J Mol Sci 20(1):162. https://doi.org/10.3390/ijms2001 0162

17. Raliya R, Saharan V, Dimkpa C, Biswas P (2017) Nanofertilizer for precision and sustainable Agriculture: current state and future perspectives. J Agric Food Chem 66(26):6487-6503. https://doi.org/10.1021/acs.jafc.7b02178

18. Mosa KA, El-Naggar M, Ramamoorthy K, Alawadhi H, El-Naggar A, Wartanian S, Ibrahim E, Hani H (2018) Copper nanoparticles induced genotoxicty, oxidative stress, and changes in Superoxide Dismutase (SOD) gene expression in cucumber (Cucumis sativus) plants. Front Plant Sci 9:872. https://doi.org/10.3389/fpls.2018.00872

19. Chen H (2018) Metal based nanoparticles in agricultural system: behavior, transport, and interaction with plants. Chem Speciat Bioavailab 30(1):123134. https://doi.org/10.1080/09542299.2018.1520050

20. Azeez L, Agbaje L, Wahab AA, Adejumo AL, Raji K (2019) Comparative effects of silver nanoparticles, sucrose and sodium chloride as osmotic solutions for tomato slices: antioxidant activity, microbial quality and modelling with polynomial regression model. South Afr J Chem 72(1):21-31. https://doi.org/10.17159/0379-4350/2019/v72a4

21. Liu J, Williams PC, Goodson BM, Geisler-Lee J, Fakharifar M, Gemeinhardt ME (2019) $\mathrm{TiO}_{2}$ nanoparticles in irrigation water mitigate impacts of aged $\mathrm{Ag}$ nanoparticles on soil microorganisms, Arabidopsis thaliana plants, and Eisenia fetida earthworms. Environ Res 172:202-215. https://doi.org/10.1016/ j.envres.2019.02.010

22. Gupta SD, Agarwal A, Pradhan S (2018) Phytostimulatory effect of silver nanoparticles (AgNPs) on rice seedling growth: An insight from antioxidative enzyme activities and gene expression patterns. Ecotoxicol Environ Saf 161:624-633. https://doi.org/10.1016/j.ecoenv.2018.06.023 
23. He J, Wang D, Zhou D (2019) Transport and retention of silver nanoparticles in soil: Effects of input concentration, particle size and surface coating. Sci Total Environ 648:102-108. https://doi.org/10.1016/j.scitotenv.2018.08.136

24. Lei C, Sun Y, Tsang DCW, Lin D (2018) Environmental transformations and ecological effects of iron-based nanoparticles. Environ Pollut 232:10-30. https://doi.org/10.1016/j.envpol.2017.09.052

25. Liu L, Li W, Song W, Guo M (2018) Remediation techniques for heavy metal contaminated soils: Principles and applicability. Sci Total Environ 633:206219. https://doi.org/10.1016/j.scitotenv.2018.03.161

26. Aziz Y, Shah GA, Rashid MI (2019) ZnO nanoparticles and zeolite influence soil nutrient availability but do not affect herbage nitrogen uptake from biogas slurry. Chemosphere 216:564-575. https://doi.org/10.1016/j. chemosphere.2018.10.119

27. Lateef A, Adeeyo AO (2015) Green synthesis and antibacterial activities of silver nanoparticles using extracellular laccase of Lentinus edodes. Not Sci Biol 7(4):405-411. https://doi.org/10.15835/nsb749643

28. Lateef A, Azeez MA, Asafa TB, Yekeen TA, Akinboro A, Oladipo IC, Azeez L, Ojo SA, Gueguim-Kana EB, Beukes LS (2016) Cocoa pod husk extract mediated biosynthesis of silver nanoparticles: its antimicrobial, antioxidant and larvicidal activities. J Nanostruct Chem 6(2):159-169. https://doi.org/10.1 007/s40097-016-0191-4

29. Lateef A, Azeez MA, Asafa TB, Yekeen TA, Akinboro A, Oladipo IC, Azeez L, Ajibade SE, Ojo SA, Gueguim-Kana EB, Beukes LS (2016) Biogenic synthesis of silver nanoparticles using a pod extract of Cola nitida: Antibacterial and antioxidant activities and application as a paint additive. J Taibah Uni Sci 10(4):551-562. https://doi.org/10.1016/j.jtusci.2015.10.010

30. Lateef A, Akande MA, Azeez MA, Ojo SA, Folarin Bl, Gueguim-Kana EB, Beukes LS (2016) Phytosynthesis of silver nanoparticles (AgNPs) using miracle fruit plant (Synsepalum dulcificum) for antimicrobial, catalytic, anticoagulant and thrombolytic applications. Nanotechnol Rev 5(6):507-520

31. Lateef A, Ojo SA, Folarin Bl, Gueguim-Kana EB, Beukes LS (2016) Kolanut (Cola nitida) Mediated synthesis of silver-gold alloy nanoparticles: antifungal, catalytic, larvicidal and thrombolytic applications. J Clust Sci 27(5):1561-1577. https://doi.org/10.1007/s10876-016-1019-6

32. Dimkpa CO, Bindraban PS (2017) Nanofertilizers: New products for the industry? J Agric Food Chem 66:6462-6473

33. Oladipo IC, Lateef A, Elegbede JA, Azeez MA, Asafa TB, Yekeen TA, Akinboro A, Gueguim-Kana EB, Beukes LS, Oluyide TO, Atanda OR (2017) Enterococcus species for the one-pot biofabrication of gold nanoparticles: Characterization and nanobiotechnological applications. J Photochem Photobiol. B: Biology 173:250-257. https://doi.org/10.1016/j.jphotobiol.2017.06.003

34. Prasad R, Bhattacharyya A, Nguyen QD (2017) Nanotechnology in sustainable agriculture: recent developments, challenges, and perspectives. Front Microbiol 8:1014. https://doi.org/10.3389/fmicb.2017.01014

35. Noori A, Donnelly T, Colbert J, Cai W, Newman LA, White JC (2019) Exposure of tomato (Lycopersicon esculentum) to silver nanoparticles and silver nitrate: physiological and molecular response. Int J Phytorem. https:// doi.org/10.1080/15226514.2019.1634000

36. Tombuloglu H, Slimani Y, Tombuloglu G, Almessiere M, Baykal A, Ercan I, Sozeri $\mathrm{H}$ (2019) Tracking of $\mathrm{NiFe}_{2} \mathrm{O}_{4}$ nanoparticles in barley (Hordeum vulgare $\mathrm{L}$.) and their impact on plant growth, biomass, pigmentation, catalase activity, and mineral uptake. Environ Nanotechnol Monit Manag 11: 100223

37. Tombuloglu H, Tombuloglu G, Slimani Y, Ercan I, Sozeri H, Baykal A (2018) Impact of manganese ferrite $\left(\mathrm{MnFe}_{2} \mathrm{O}_{4}\right)$ nanoparticles on growth and magnetic character of barley (Hordeum vulgare L.). Environ Pollut 243(Pt B): 872-881. https://doi.org/10.1016/j.envpol.2018.08.096

38. Kisan B, Shruthi H, Sharanagouda H, Revanappa SB, Pramod NK (2015) Effect of nano zinc oxide on the leaf physical and nutritional quality of spinach. Agrotechnol 5:135

39. Duhan JS, Kumar R, Kumar N, Kaur P, Nehra K, Duhan S (2017) Nanotechnology: the new perspective in precision agriculture. Biotechnol Rep 15:11-23. https://doi.org/10.1016/j.btre.2017.03.002

40. Upadhyaya H, Begum L, Dey B, Nath PK, Panda SK (2017) Impact of calcium phosphate nanoparticles on rice plant. J Plant Sci Phytopathol. https://doi. org/10.29328/journal.jpsp.1001001

41. Falowo AB, Mukumbo FE, Idamokoro EM, Lorenzo JM, Afolayan AJ, Muchenje V (2018) Multi-functional application of Moringa oleifera Lam. in nutrition and animal food products: A review. Food Res Int 106:317-334. https://doi.org/10.1016/j.foodres.2017.12.079
42. Rocchetti G, Blasi F, Montesano D, Ghisoni S, Marcotullio MC, Sabatini S, Cossignani L, Lucini L (2018) Impact of conventional/non-conventional extraction methods on the untargeted phenolic profile of Moringa oleifera leaves. Frin. https://doi.org/10.1016/j.foodres.2018.11.046

43. Azeez L, Oyedeji OA, Adebisi SA, Adejumo AL, Tijani KO (2017) Chemical components retention and modelling of antioxidant activity using neural networks in oven dried tomato slices with and without osmotic dehydration pre-treatment. Food Measure 11(4):2247-2258. https://doi.org/1 0.1007/s1 1694-017-9609-z

44. Bolarinwa IF, Aruna TE, Raji AO (2019) Nutritive value and acceptability of bread fortified with moringa seed powder. J Saudi Soc Agric Sci 18(2):195200. https://doi.org/10.1016/j.jssas.2017.05.002

45. El-Deep MH, Dawood MAO, Assar MA, ljiri D, Ohtsuk A (2019) Dietary Moringa oleifera improves growth performance, oxidative status, and immune related gene expression in broilers under normal and high temperature conditions. J Ther Biol 82:157-163. https://doi.org/10.1016/j. jtherbio.2019.04.016

46. Ben-Moshe T, Frenk S, Dror I, Minz D, Berkowitz B (2013) Effects of metal oxide nanoparticles on soil properties. Chemosphere 90(2):640-646. https:// doi.org/10.1016/j.chemosphere.2012.09.018

47. Page A, Miller RH, Keeney DR (1982) Soil Analysis Part 2. Chemical and microbiological properties. ASA, SSSA, Madison, Wisconsin, USA

48. Motsara MR, Roy RN (2008) Guide to laboratory establishment for plant nutrient analysis. Fertilizer and plant nutrition bulletin. Food and Agriculture Organization of the United Nations, Rome

49. Arnon DI (1949) Copper enzymes in chloroplasts. Phenol oxidase in Beta vulgaris. Plant Physiol 24:1-15

50. Conway JR, Keller AA (2016) Gravity-driven transport of three engineered nanomaterials in unsaturated soils and their effects on soil $\mathrm{pH}$ and nutrient release. Water Res 98:250-260. https://doi.org/10.1016/j.watres.2016.04.021

51. Verma SK, Das AK, Patel MK, Shah A, Kumar V, Gantait S (2018) Engineered nanomaterials for plant growth and development: a perspective analysis. Sci Total Environ 630:1413-1435. https://doi.org/10.1016/j.scitotenv.2018.02.313

52. Fernandes JP, Mucha AP, Francisco T, Gomes CR, Almeida CMR (2017) Silver nanoparticles uptake by salt marsh plants - implications for phytoremediation processes and effects in microbial community. Marine Poll Bull 119(1):176-183. https://doi.org/10.1016/j.marpolbul.2017.03.052

53. Grün A, Manz W, Kohl WL, Meier F, Straskraba S, Jost C, Drexel R, Emmerling C (2019) Impact of silver nanoparticles (AgNP) on soil microbial community depending on functionalization, concentration, exposure time, and soil texture. Environ Sci Eur 31(1):15. https://doi.org/10.1186/s12302-019-0196-y

54. Rashid MI, Shahzadd T, Shahid M, Ismaila IMI, Shah GM, Almeelbi T (2017) Zinc oxide nanoparticles affect carbon and nitrogen mineralization of Phoenix dactylifera leaf litter in a sandy soil. J Hazard Mater 324(15):298-305. https://doi.org/10.1016/j.jhazmat.2016.10.063

55. Elemike EE, Uzoh IM, Onwudiwe DC, Babalola OO (2019) The role of nanotechnology in the fortification of plant nutrients and improvement of crop production. Appl Sci 9:499. https://doi.org/10.3390/app9030499

56. Shi J, Ye J, Fang H, Zhang S, Xu C (2018) Effects of copper oxide nanoparticles on paddy soil properties and components. Nanomat 8(10): 839-853. https://doi.org/10.3390/nano8100839

57. Omar FM, AbdulAziz H, Stoll S (2014) Stability of ZnO Nanoparticles in solution: influence of $\mathrm{pH}$, dissolution, aggregation and disaggregation Effects. J Colloid Sci Biotechnol 3:1-10

58. Naeem M, Naeem MS, Ahmad R, Ihsan MZ, Ashraf MY, Hussain Y, Fahad S (2018) Foliar calcium spray confers drought stress tolerance in maize via modulation of plant growth, water relations, proline content and hydrogen peroxide activity. Arch Agron Soil Sci 64(1):116-131. https://doi.org/10.1080/ 03650340.2017.1327713

59. Hayes PE, Clode PL, Pereira CG, Lambers H (2019) Calcium modulates leaf cell specific phosphorus allocation in Proteaceae from south-western Australia. J Exp Bot 70(15):3995-4009. https://doi.org/10.1093/jxb/erz156

60. Hosseini SA, Pluchon ERS, Ali N, Billiot B, Yvin J (2019) Calcium application enhances drought stres tolerance in sugar beet and promotes plant biomass and beetroot sucrose concentration. Int J Mol Sci 20(15):3777. https://doi.org/10.3390/ijms20153777

61. Praveen A, Khan E, Ngiimei S, Perwez M, Sardar M, Gupta M (2017) Iron oxide nanoparticles as nano-adsorbents: a possible way to reduce arsenic phytotoxicity in indian mustard plant (Brassica juncea L.). J Plant Growth Regul. 37(2):612-624. https://doi.org/10.1007/s00344-017-9760-0 
62. Gong X, Huang D, Liu Y, Peng Z, Zeng G, Xu P, Cheng M, Wang R, Wan J (2018) Remediation of contaminated soils by biotechnology with nanomaterials: bio-behaviour, applications, and perspectives. Crit Rev Biotechnol 38(3):455-468. https://doi.org/10.1080/07388551.2017.1368446

63. Elmer WH, White JC (2018) The future of nanotechnology in plant pathology. Annu Rev Phytopathol 56(1):111-133. https://doi.org/10.1146/a nnurev-phyto-080417-050108

64. Xiong T, Austruy A, Pierart A, Shahid M (2016) Kinetic study of phytotoxicity induced by foliar lead uptake for vegetables exposed to fine particles and implications for sustainable urban agriculture. J Environ Sci:1-12

65. Hu W, Tian SB, Di Q, Duan SH, Dai K (2018) Effects of exogenous calcium on mesophyll cell ultrastructure, gas exchange, and photosystem II in tobacco (Nicotiana tabacum Linn.) under drought stress. Photosynthetica 56(4):12041211. https://doi.org/10.1007/s11099-018-0822-8

66. Esposito M, De Roma A, Cavallo S, Miedico O, Chiaravalle E, Soprano V, Baldi L, Gallo P (2019) Trace elements in vegetables and fruits cultivated in Southern Italy. J Food Compos Anal 84:103302. https://doi.org/10.1016/j. jfca.2019.103302

67. Qian L, Zhang C, Zuo F, Zheng L, Li D, Zhang A, Zhang D (2019) Effects of fertilizers and pesticides on the mineral elements used for the geographical origin traceability of rice. J Food Compos Anal 83:103276. https://doi.org/1 0.1016/j.jfca.2019.103276

68. Lefticariu L, Sutton SR, Lanzirotti A, Flynn TM (2019) Enhanced immobilization of arsenic from acid mine drainage by detrital clay minerals. ACS Earth Space Chem. https://doi.org/10.1021/acsearthspacechem.9b00203

\section{Publisher's Note}

Springer Nature remains neutral with regard to jurisdictional claims in published maps and institutional affiliations.

\section{Submit your manuscript to a SpringerOpen ${ }^{\circ}$ journal and benefit from:}

- Convenient online submission

- Rigorous peer review

- Open access: articles freely available online

High visibility within the field

- Retaining the copyright to your article

Submit your next manuscript at $\boldsymbol{\nabla}$ springeropen.com 